\title{
El tipi mobil LiDAR teknolojisinin orman envanterlerinde kullanımı: Artvin-Şavşat örneği
}

\author{
Using handheld mobile LiDAR technology in forest inventories: Artvin-Şavşat case
}

\author{
Can VATANDAŞLAR ${ }^{1}$ \\ Mustafa ZEYBEK ${ }^{2}$ \\ Ergin Çağatay ÇANKAYA ${ }^{3}$ \\ Tugay DEMIRASLAN ${ }^{3}$ (D) \\ Cahit ŞAHIN ${ }^{3}$ iD \\ Yasin GÜNDÜZ ${ }^{3}$ \\ Ümit KORKMAZ ${ }^{3}$ (ID \\ Mehmet Latif $\mathrm{AVCI}^{3}$ (D) \\ ${ }^{1}$ Artvin Çoruh Üniversitesi, Orman Fakül-
tesi, Artvin
${ }^{2}$ Selçuk Üniversitesi, Güneysınır Meslek
Yüksekokulu, Konya
${ }^{3}$ Orman Genel Müdürlüğü, Ankara
}

Sorumlu yazar (Corresponding author)

Can VATANDAŞLAR

canvatandaslar@artvin.edu.tr

Geliş tarihi (Received)

01.11 .2021

Kabul Tarihi (Accepted)

12.12.2021

Sorumlu editör (Corresponding editor) Mustafa BATUR

mustafabatur01@ogm.gov.tr

Atıf (To cite this article): Vatandașlar, C. , Zeybek, M. , Cankaya, E. C.. , Demiraslan, T. , Sahin, C. , Gündüz, Y., Korkmaz, Ü. \& Avc1, M. L. (2022). El tipi mobil LiDAR teknolojisinin orman envanterlerinde kullanımı: Artvin-Şavşat örneğ . Ormancılık Araștırma Dergisi , 9 (1), 81-96 DOI: $10.17568 /$ ogmoad.1016879

\section{$\ddot{O} z$}

$\mathrm{Bu}$ çalışmanın amacı; (i) orman envanterlerinde mobil lazer tarama (LiDAR) teknolojisinden yararlanma olanaklarını araştırmak ve (ii) meşcere parametrelerine iliş̧in LiDAR verilerini, uygulamada tespit edilen değerlerle karşılaștırmaktır. Bu doğrultuda, Şavşat'ta arazi ölçümleri gerçekleştirilen örnek alanlar el tipi LiDAR cihazı ile taranmıștır. Daha sonra örnek alanlardan elde edilen veri setleri birbiriyle karşılaştırılarak LiDAR'ın hassasiyeti sınanmıştır. Yapılan istatistik testler sonucunda, LiDAR ve çapölçer ile ölçülen ağaçların çapları arasında anlamlı bir fark bulunmamıştır $(p>0,05)$. Yersel ölçümler referans kabul edilirse; göğüs çapı, ağaç sayısı, meşcere üst boyu ve meşcere hacmi parametreleri LiDAR cihazıyla sırasıyla; ort. $0,68 \mathrm{~cm}$ $(\% 2,2), 14 \mathrm{ad} / \mathrm{ha}(\% 2,0), 0,8 \mathrm{~m}(\% 3,4)$ ve $155,7 \mathrm{~m}^{3} / \mathrm{ha}(\% 24,6)$ hata ile tahmin edilebilmiştir. Hacimde gözlenen yüksek hata üzerine, arazideki altı adet ağaç önce LiDAR ile dikili halde taranmış ve sonra kesilerek, bölümleme yöntemiyle hacimlendirilmiştir. Yerde ölçülen gövde hacimlerinin LiDAR ile ort. $0,061 \mathrm{~m}^{3}(\% 5,1)$ hata ile tespit edilebildiği görülmüştür. Dolayısıyla, meşcere hacimlerindeki yüksek hata oranlarının LiDAR yönteminden değil, envanterde kullanılan tek girişli hacim tablolarından kaynaklandığı anlaşılmıştır. Buna karşılık, LiDAR nokta bulutları üzerinden ağaç türü ve meşcere tipleri belirlenememiştir. Çalışmanın sonunda, amenajman planlarındaki birçok meşcere parametresine ait değerlerin mobil LiDAR teknolojisiyle arazide daha az vakit harcanarak kabul edilebilir doğruluk düzeylerinde hesaplanabildiği sonucuna ulaşılmıştır.

Anahtar Kelimeler: Mobil lazer tarama (LiDAR), GeoSLAM ZEBHORIZON, orman amenajmanı ve planlama

\begin{abstract}
This study aims to; (i) demonstrate how to use handheld laser scanning (LiDAR) technology in forest inventories, and (ii) compare stand parameters calculated with LiDAR and traditional measurements. To this end, sample plots were scanned by a LiDAR device in Şavşat, NE Turkey. Then, the sensitivity of LiDAR data was examined by comparing it with ground truth. No significant difference was found between tree DBHs measured by LiDAR and caliper ( $p>0.05)$. Taking ground measurements as reference; DBH, the number of trees, stand top height, and stand volume parameters were captured by LiDAR with mean errors of $0.68 \mathrm{~cm}(2.2 \%), 14$ trees/ha (2.0\%), $0.8 \mathrm{~m}(3.4 \%)$, and $155.7 \mathrm{~m}^{3} /$ ha $(24.6 \%)$, respectively. Since the mean error was high for stand volume, six standing trees were scanned by LiDAR, and then, they were felled and volumized using the section method. Ground measurements showed that LiDAR calculated stem volumes with a mean error of $0.061 \mathrm{~m}^{3}(5.1 \%)$. Thus, the high error rate in stand volumes was attributed to the reference data derived by existing volume tables. On the other hand, tree species and stand types could not be identified with LiDAR. It was concluded that mobile LiDAR technology could calculate many stand parameters with acceptable accuracy levels efficiently.
\end{abstract}

Keywords: Light detection and ranging (LiDAR), GeoSLAM ZEBHORIZON, forest management planning 


\section{Giriş}

Orman envanteri çalışmaları orman amenajmanı planlama sürecinin en masraflı, en zahmetli ve en çok zaman alan aşamasıdır (Eraslan, 1982; Kalıpsız, 1984). Tek bir Orman İşletme Şefliği (OİŞ) için aylarca sürebilen bu çalışmalar, plan ünitesinin verimli ormanlarına belirli aralık-mesafelerle sistematik olarak dağıtılan örnek alanların içine giren ve insanın gögüs yüksekliğindeki $(1,30 \mathrm{~m})$ çap $18,0 \mathrm{~cm}$ ve daha kalın olan tüm ağaçların türü, adedi, gögüus çapı, kapalılığı gibi parametrelerin yersel ölçüm ve gözlemlere dayalı olarak tespitine dayanmaktadır. Ayrıca, bonitet sınıfının saptanması için hakim ağaçların boyu ve yaşı; hacim ve hacim artım tabloları oluşturabilmek için orta ağacın yaşı, boyu, çift kabuk kalınlığı ve son on yıllık halka genişliği gibi parametreler de ölçülerek envanter karnelerine kaydedilmektedir (OGM, 2017). Orman ekosistemlerinin dinamik yapısı, söz konusu envanterlerin her 10 ya da 20 yilda bir tekrarlanmasını gerektirmektedir. Dolayısıyla ekosistem tabanlı fonksiyonel orman amenajman planları yenilenirken -en azından- alan ve ağaç serveti/ artım envanterlerinin sıfırdan yapılması bir zorunluluktur.

Günümüzde uzaktan algılama ve robotik teknolojilerindeki ilerlemelere paralel olarak, lazer tarama (LiDAR-Light Detection And Ranging) sistemleri de hızla gelişmektedir. Çeşitli LiDAR sistemleri ile ortamdaki objelerin yapısal özellikleri ve konum bilgisi 3 boyutlu (3B) olarak elde edilebilmektedir. Daha sonra bu veriler bilgisayar ortamında analiz edilerek, istenilen parametrelere ait metrik ölçümler belirli güven aralığında gerçekleştirilebilir. Böylece, özellikle orman şartlarında oldukça zor olabilen yersel ölçme işlemleri azaltılabilir, arazide geçirilen zaman ve maliyetten tasarruf edilebilir.

LiDAR teknolojisi esasen lazer 1şınları ile ortamın taranmasından ibarettir. Bu yüzden LiDAR sistemlerine sıklıkla lazer tarayıcı da denir. Tarayıcıdan etrafa saçılan lazer 1şın demetleri, ortamdaki objelere çarparak tarayıcıya geri dönmekte ve bu esnada geçen zaman çok hassas şekilde ölçülerek kaydedilmektedir. Işığın hızı bilindiğinden, ortamdaki objelerin tarayıcıya olan mesafesi ayrıntılı olarak hesaplanmakta ve böylece ortam, bilgisayarda 3B olarak canlandırılabilmektedir. Buna rekonstrüksiyon model denmektedir. Rekonstrüksiyon modeller üzerinden istenilen objeye ait çeşitli parametre (çap, boy, alan, hacim vd.) değerleri hassas şekilde ölçülebilir (Vatandaşlar ve Zeybek, 2021).

LiDAR sistemleri (Şekil 1) temelde dört gruba ayrılmaktadır: (i) Uydu tabanlı sistemler, (ii) Havasal sistemler, (iii) Yersel sistemler ve (iv) Mobil sistemler (URL-1; URL-2; URL-3). Uydu tabanlı sistemler; ICESat-2 ve ISS gibi uydu platformlar1 ya da uzay istasyonları üzerine entegre edilmiş lazer tarayıcılardan ibarettir ve çok geniş orman alanlarının (örn. tropik ormanlar) düşey yapıları ya da ormansızlaşma hakkında kaba bilgiler elde etmek için kullanılmaktadırlar. Havasal sistemler; uçak, helikopter ya da insansız hava araçları (İHA) üzerine monte edilen tarayıcı sensörler yardımıyla geniş orman arazilerinin (örn. orman işletme müdürlüğüOİM) yatay ve düşey yapıları hakkında orta hassasiyette bilgi toplayabilir. Yersel statik sistemler; diğer sistemlere nazaran çok daha hassas ve detaylı bilgi toplarlar. $\mathrm{Bu}$ sistemler ile orman ağaçlarının dal ve yaprakları bile birbirinden ayrılarak modellenebilmektedir (Yurtseven ve ark., 2019).

Ancak, yersel sistemler nispeten ağır ve statik (sabit) oldukları için orman arazi şartlarında kullanımı pratik değildir. Tripod üzerine kurulan bu tarayıcıların orman içinde taşınmaları da zordur. Ayrıca, tek bir örnek alanda dahi tüm ağaçları her yönden modelleyebilmek için en az birkaç farklı noktada cihaz kurulumu yapılıp tekrarlı veri alınması gereklidir. Toplanan veriler daha sonra dijital ortamda manuel olarak çakıştırılmalıdır (alignment). Bu işlem, veri analiz süreçlerini oldukça uzatmaktadır (Vatandaşlar ve Zeybek, 2020).
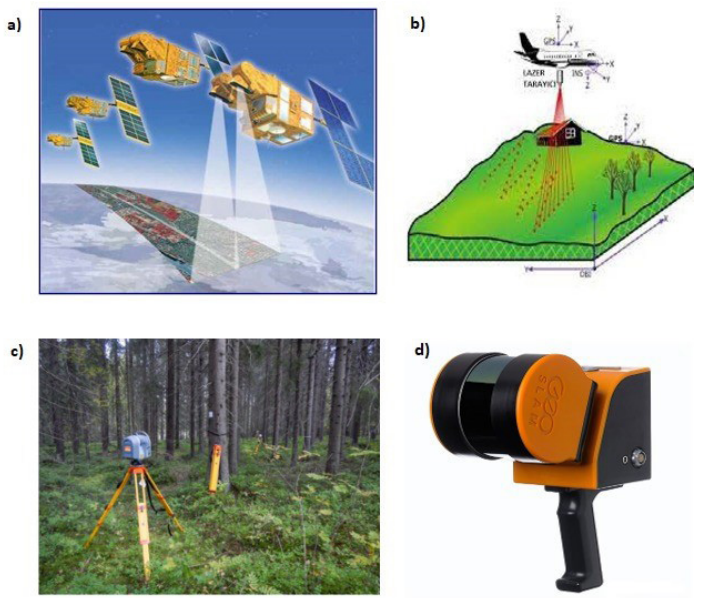

Şekil 1. Çeşitli platformlarda bulunan LiDAR sistemleri: a) Uydu, b) Havasal (URL-1), c) Yersel statik (URL-2), d) Yersel mobil (URL-3).

Figure 1. LiDAR systems on different platforms: a) Space-borne, b) Airborne (URL-1), c) Terrestrial static (URL-2), d) Terrestrial mobile (URL-3).

Özellikle son yıllarda LiDAR sensörlerinin boyutları giderek küçülmüş ve mobil hale gelmiştir. Mobil sistemler; (i) El tipi tarayıcılar, (ii) Kişisel (giyilebilen) tarayıc1lar, (iii) Araca monteli taray1c1lar ve (iv) Mobil cihazlara (telefon, tablet) entegre tarayıcılar olarak dört gruba ayrılabilir. 
Ormancılık çalışmaları için ideal görülen el tipi tarayıcılar, hafif ve mobil oluşu sayesinde operatör tarafından orman içinde rahatlıkla dolaştırılabilmektedir. Böylece örnek alanların 3B nokta bulutu verisi üretilebilmekte, diğer bir ifadeyle; orman bilgisayar ortamında yeniden canlandırılmaktadır (Şekil 2). Buna ilaveten, oluşturulan rekonstrüksiyon modeller üzerinden istenilen birçok detaya ait bilgi, dijital ortamda yüksek hassasiyetle türetilebilmektedir (Şekil 2a-b). Dolayısıyla, el tipi mobil lazer tarayıcılar başta orman envanteri olmak üzere diğer birçok ormancılık uygulaması için önemli firsatlar sunmaktadir.

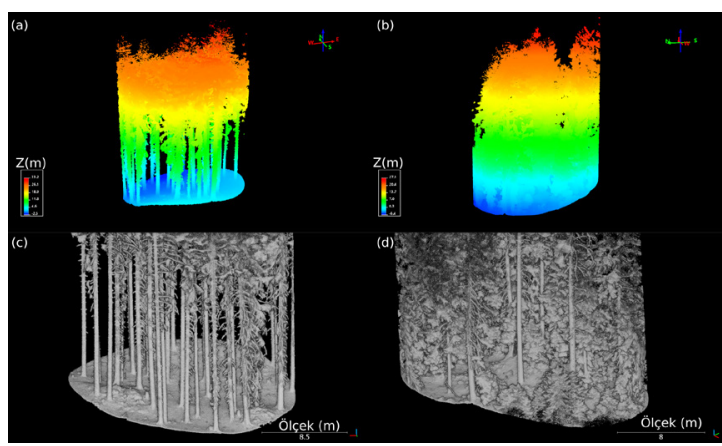

Şekil 2. El tipi mobil LiDAR sistemiyle ormanda tarama yapılarak üretilmiş 3B veriler: $a-b)$ Yükseklik bilgisini içeren nokta bulutları, c-d) Aynı alanlara ait görselliği artırılmış nokta bulutları.

Figure 2. 3D forest data captured by handheld mobile LiDAR system: a-b) Point clouds with height information, c-d) Dense point clouds of the same plots.

Bu araştırma çalışmasının amacı; (i) Türkiye'de geleneksel yöntemlerle gerçekleştirilen orman envanteri çalışmalarında yeni nesil LiDAR teknolojilerinden biri olan el tipi mobil LiDAR sistemlerinden yararlanma olanaklarının araştırılması ve (ii) meşcere parametrelerine ilişkin LiDAR sistemiyle elde edilen değerlerin uygulamada tespit edilen değerlerle karşılaştırılarak LiDAR verisinin doğruluğunun test edilmesidir. Makalede, Orman Genel Müdürlüğü (OGM) Orman İdaresi ve Planlama Daire Başkanlığ 1 (OİPD) tarafından Artvin Orman Bölge Müdürlügü'nde (OBM) gerçekleştirilen orman amenajman planı yenileme çalışmaları kapsamında yapılan LiDAR uygulama sonuçlarının bir kısmına yer verilmiştir.

\section{Materyal ve Metot}

\subsection{Calıșma alanı}

Araştırma için plan ünitesi olarak Artvin'de bulunan Karagöl-Sahara Milli Parkı (MP) ve Sahara OİŞ seçilmiştir (Şekil 3). Karagöl-Sahara MP idari açıdan Doğa Koruma ve Milli Parklar Genel Müdürlüğü'ne, Sahara OİŞ ise Artvin OBM Şavşat
OİM'ne bağlıdır. Artvin'in çalışma alanı olarak seçilmesinde birden çok faktör rol oynamıştır;

(i) Artvin ormanlarının oldukça sarp arazilerde yer almas1, (ii) MP, korunan alan statüsünde olduğundan buradaki meşcerelerin bakım görmemiş ve dolayısıyla oldukça kompleks ve sık yapıda olması, (iii) çalışma alanındaki asli tür çeşitliliğinin yüksek oluşu. Bu nedenlerle, Artvin'in zor orman koşullarında tatmin edici sonuçlar üretebilen bir teknoloji ve yöntemin, ülkemizin diğer ormanlarında daha verimli çalışacağı ve dolayısıyla güvenle kullanılabileceği düşünülmüştür.

Her iki plan ünitesindeki hakim ağaç türleri ladin (Picea orientalis), göknar (Abies nordmanniana ssp. nordmanniana) ve sarıçamdır (Pinus sylvestris). Plan üniteleri genellikle bu üç türün saf ve karışık ormanlarından oluşmaktadır. Buna ilaveten; kavak (Populus sp.), meşe (Quercus sp.) gibi yapraklı türlerin meşcerelerine de rastlanmaktadır. Yörede, Doğu Karadeniz ve Doğu Anadolu iklim zonları arasındaki geçiş tipi iklimi egemendir (OGM 2013). Plan ünitelerine en yakın meteoroloji istasyonu olan Şavşat Otomatik Meteoroloji Gözlem İstasyonu'nda yıllık ort. toplam yağış miktarı $600 \mathrm{~mm}$ seviyelerindedir. Y1llık sicaklık ort. ise yaklaşık $10^{\circ} \mathrm{C}$ 'dir (MGM, 2012).

Milli Park'ın kuzey bölümünde bulunan Karagöl esasında bir heyelan gölü olup, özellikle yaz aylarında oldukça fazla turist çekmektedir. Güney kesimde yer alan Sahara bölümü ise ort. $1800 \mathrm{~m}$ yükseklikte olup, yaylacılık faaliyetleri ve şenlik alanları ile ünlüdür. Sahara'da geleneksel olarak her yıl yaz aylarında geniş katılımlı Pancar Şenlikleri ve diğer etkinlikler düzenlenmektedir (Orhan, 2015). İkinci çalışma alanı olan Sahara OİŞ ise; 2020 yılında idari sınırları yeniden düzenlenen Veliköy ve Şavşat OİŞ’lerinden ayrılan alanlardan oluşturulmuş yeni bir şefliktir. Her iki çalışma alanı da birbirine bitişiktir (Şekil 3).

\subsection{Veri kaynağı}

$\mathrm{Bu}$ araştırmanın ana veri kaynağını oluşturan örnek alanlardaki ağaçlar, el tipi mobil LiDAR sistemlerinden GeoSLAM ZEB-HORIZON cihazı ile modellenmiştir. Şekil 1'de gösterilen cihaz, İngiliz GeoSLAM firmasınca geliştirilip piyasaya sunulmuştur (Cadge, 2016). ZEB-HORIZON, yine daha önce GeoSLAM tarafından üretilen ZEB1 ve ZEBREVO cihazlarının daha gelişmiş bir versiyonudur. ZEB-REVO'da $20 \mathrm{~m}$ olan tarama menzili, ZEB-HORIZON'da 100 m'ye çıkarılmıştır. Böylelikle çok daha kısa sürede daha geniş arazilerin 3B nokta bulutu üretilebilmektedir. Cihaz, saniyede 300.000 nokta okuyabilmektedir. Bu okuma say1- 
s1 objelerin yansıtma oranına bağlıdır. Sinyal geri yansıma yoğunluğu seviyesi de (intensity) ayrıca kayıt edilmektedir.

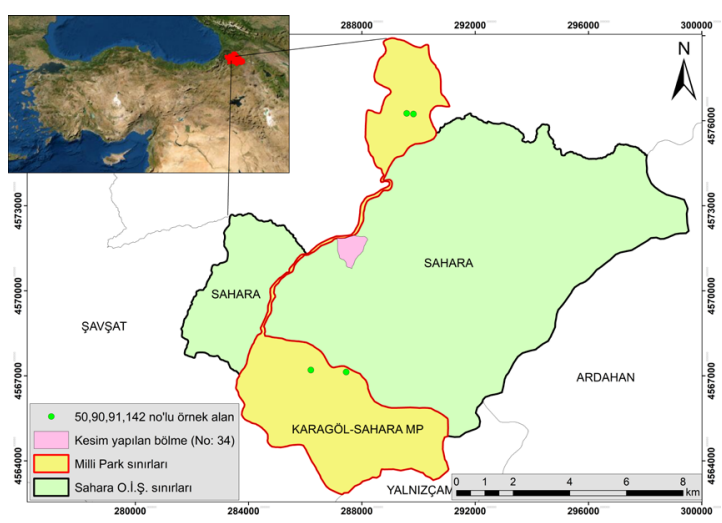

Şekil 3. Çalışma alanı ve örnek noktaların konumu.

Figure 3. The map of the study area with sample plots.

Cihaz, döner başlıklı lazer tarayıcı, ataletsel ölçüm ünitesi (IMU) ve veri kayıt ünitesi (data logger) olmak üzere üç ana üniteden oluşmaktadır. Bunlara ilaveten, 4K kayıt yapabilen bir video kamera da cihaza monte edilebilmektedir. Bu durumda, cihaz ağırlığ 1 yaklaşık 1,5 kg olmaktadır. Robotik teknolojisinde ve otonom araçlarda kullanılan Eşzaman11 Konumlandirma ve Haritalama (SLAM) algoritmasını kullanan cihaz, açık ya da kapalı ortamları Küresel Uydu Seyrüsefer Sistemi'ne (GNSS) ihtiyaç duymadan otomatik şekilde haritalayabilmektedir. Diğer bir ifadeyle, el tipi mobil LiDAR sistemleri GPS olmadan lokal koordinat sisteminde haritalama yapabilme yeteneğine sahiptirler. Bu yetenek, özellikle tam kapalı meşcerelerde gerçekleştirilen ormancılık çalışmalarında büyük avantaj sağlamaktadır (Vatandaşlar ve Zeybek, 2021). Çünkü böyle meşcerelerin içinde GPS sinyallerini etkili şekilde alabilmek oldukça güçtür.

SLAM algoritmasının diğer önemli avantajı; veri alımı esnasında her saniyede toplanan noktaları, ölçme anından birkaç saniye önce toplanan nokta bulutlarıyla otomatik olarak eşleştirmek suretiyle yekpare nokta bulutu üretme kapasitesidir. Böylece, yersel (statik) LiDAR sistemlerinde olduğu gibi, aynı alana ait farklı açılardan alınmış ayrık nokta bulutlarının çakıştırılmasına (alignment) gerek duyulmamakta ve veri analiz süreci oldukça kısalmaktadır.

$\mathrm{Bu}$ araştırma çalışmasında faydalanılan "el tipi mobil LiDAR sistemi” için makalenin devamında kısaltması "LiDAR” kullanılmıştır.

\subsection{LiDAR ile veri alımı (tarama) ve ön işleme}

$\mathrm{Bu}$ araştırma kapsamında 12. Orman Amenajman Başmühendisliği ile birlikte geleneksel envanter yöntemlerine göre yersel ölçmesi yapılacak örnek alanlara gidilerek envanter karnesi doldurulmuş ve devamında LiDAR cihazı ile veri alımı (tarama) işlemi gerçekleştirilmiştir (Şekil 4). Makalede geleneksel orman envanteri yönteminin (Kayacan ve ark., 2016; OGM, 2017) detayına girilmemiş, yalnızca LiDAR ile envanter yöntemleri tanıtılmıştır.

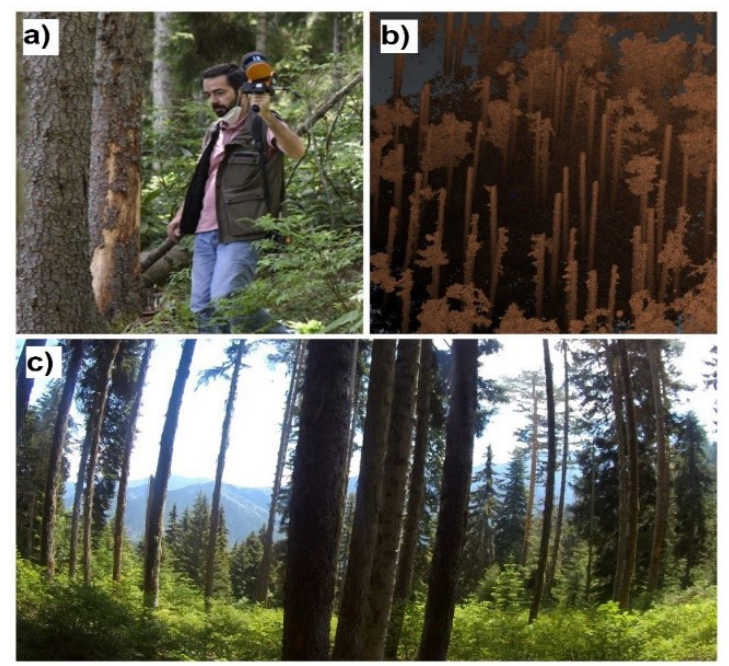

Şekil 4. LiDAR cihazıyla a) Örnek alanın taranması, b) Örnek alanın 3B nokta bulutu (görsellik açısından veri tepeden kesilmiştir), c) Tarama esnasında eşzamanlı çekilen 4K video kaydi.

Figure 4. a) Data capturing in a sample plot, b) 3D point cloud of the same plot (data was cross-sectioned for visual improvement), c) $4 \mathrm{~K}$ video record of the same plot.

LiDAR ile veri alan operatör, örnek alan merkezine çakılan kazıktan başlamak suretiyle örnek alanın tamamını kapsayacak şekilde serbest yürüyüş gerçekleştirmiştir. Serbest yürüyüşte örnek alan içine giren tüm ağaçları dört yönden kapsayacak şekilde birkaç tur atılmakta ve başlangıç noktasına geri dönülerek veri alımı durdurulmaktadır. Cihazla veri alım işlemi $400 \mathrm{~m}^{2}$ 'lik bir örnek alan için yaklaşık 5-6 dk. sürmektedir. Ölçme süresi topografya, meşcere yapısı ve diri örtü yoğunluğuna bağlı olarak değişebilmektedir.

Daha sonra cihazın veri kayıt ünitesine kaydedilen ham veri USB flash disk'e aktarılmıştır. Bilgisayar ortamına aktarilan veriler, cihazla gelen GeoSLAM Hub programı ile dizüstü bilgisayarda işlenmiş ve ".laz" uzantılı sıkıştırılmış ".las" formatlı 3B nokta bulutu dosyası üretilmiştir (Şekil 4). GeoSLAM Hub programında varsayılan (default) parametrelerle işlem yapılmıştır. Tarama esnasında ortaya çıkan parazit (noise) ve tekrarlı noktaların temizlenmesi de bu aşamada gerçekleşmektedir. Aynı zamanda yoğun veriye seyreltme işlemi de uygulanmaktadır. Veri analiz performansının artı- 
rılması ve doğruluk faktörü de göz önünde bulundurulduğunda seyreltmenin seviyesi çok önemlidir.

Tüm bu işlemlere "veri ön işleme" denmekte ve ham veri böylelikle analize hazır hale getirilmektedir. $5 \mathrm{dk}$.'lik bir tarama sonunda elde edilen ham verinin ön işlemesi de dizüstü bilgisayar ile $5 \mathrm{dk}$. sürmektedir. Cihaz tek oturumda $15 \mathrm{dk}$. kesintisiz tarama yapabilme kapasitesine sahiptir. Tarama süresi arttıkça ön işleme süresi de doğru orantılı olarak artacaktır. Taramaya başlandığ 1 anda cihaza entegre edilen $4 \mathrm{~K}$ video kamera da kayda başlamakta, böylelikle örnek alanların yüksek kaliteli görüntü kayıtları da eşzamanlı olarak elde edilmektedir (Şekil 4).

\subsection{Veri analizi}

Ülkemizdeki orman amenajmanı planlama çalışmaları sürecinde, örnek alanlar içerisindeki ölçülen ağaç konumlarının koordinatlı olması gerekmemektedir. Örnek alan merkezinin el GPS'i ile 5-10 m hassasiyette kaydedilen koordinatı yeterli olmaktadır (OGM, 2017). Dolayısıyla, LiDAR verisi üzerinden ölçümlerin $\left(\mathrm{d}_{1,30}, \mathrm{~h}, \mathrm{~V}\right)$ yapılabilmesi için 3B nokta bulutunun gerçek yer koordinatlarında olması gerekli değildir. Ancak, envanter karnesindeki değerlerle birebir karşılaştırma yapabilmek için öncelikle nokta bulutlarının örnek alan sınırlarına tam uyacak şekilde kesilmesi şarttır. Bunun için, cihazın tam olarak merkez kazık üzerinde çalıştırılması gerekmektedir. Böylelikle, rölatif (bağ1l) koordinat sisteminde X:0, Y:0, Z:0 olmakta ve bu konum, nokta bulutu verisinin de merkezi olarak kabul edilmektedir.

Araştırmamızda, söz konusu nokta merkez kabul edilerek, daire şeklindeki örnek alanların büyüklügüne $\left(400 \mathrm{~m}^{2}, 600 \mathrm{~m}^{2}, 800 \mathrm{~m}^{2}\right)$ göre uygun yarıçap genişlikleri $(11,28 \mathrm{~m}, 13,82 \mathrm{~m}, 15,96 \mathrm{~m})$ ayarlanmış ve veriler buna göre kesilmiştir. 3B nokta bulutlarının arazide alınan örnek alanlar uyarınca hizalanıp kesilmesi 3DReshaper yazılımında gerçekleştirilmiştir.

Karne ve verideki ağaçların tek tek eşleştirilmesi ise semt açısı hesabıyla yapılmıştır. Ülkemizde uygulanan geleneksel orman envanteri yöntemi uyarınca, örnek alandaki ağaçların ölçümüne kuzeyden başlanır, saat yönünde dönülerek her bir ağaca numara verilir ve bu şekilde ilerlenir (OGM, 2017). Arazide yersel ölçümler yapılırken bu kurala riayet edilmiştir. Diğer yandan, LiDAR verisi rölatif koordinat sisteminde gelmektedir. Dolayısıyla örnek alan sınırlarına göre kesilen nokta bulutlarında kuzey yönü ve her ağacın merkezden kuzeyle yaptığ açı (semt açısı) bellidir. Bu sayede nokta bulutlarındaki her bir ağaç, envanter karnesindekilerle eşleştirilebilmiştir.

\subsubsection{Nokta bulutlarının yer/yerüstü olarak sınıflandırılması ve normalizasyon}

Eğimli arazilerdeki ormanlarda ağaç boyu ve göğüs çap1 $\left(\mathrm{d}_{1,30}\right)$ parametrelerine ilişkin değerler yer seviyesine göre hesaplandığı için topografyayı (zemin) temsil eden noktaların tespit edilmesi elzemdir. Elde edilen topografik noktalar üzerinden yüzey (mesh) modeli veya sayısal yükseklik modeli (SYM) üretilerek, yerüstü yani vejetasyonu temsil eden tüm noktaların zemine olan mesafeleri hesaplanmalıdır. Bu durumda, topografik model, referans obje olmaktadır. Karşılaştırma noktaları da ağacı temsil eden noktalar alınarak rölatif $\mathrm{Z}$ ekseni (yükseklik) yeniden hesaplanır. Tek ağaçlara ait bilgilerin çıkarımında noktaların yer/yerüstü olarak sınıflandırılması ve normalizasyon rutin bir işlemdir (Liu ve ark., 2021; Trochta ve ark., 2017; Wang ve ark., 2019).

$\mathrm{Bu}$ araştırma çalışmasında yüzey modelleri eğim temelli bir algoritmayla 3DReshaper yazılımı ile üretilmiştir. Daha sonra, yüzey (mesh) model olarak elde edilen zemin ile yerüstünü (vejetasyonu) temsil eden tüm noktalar karşılaştırılmıştır (Şekil 5).
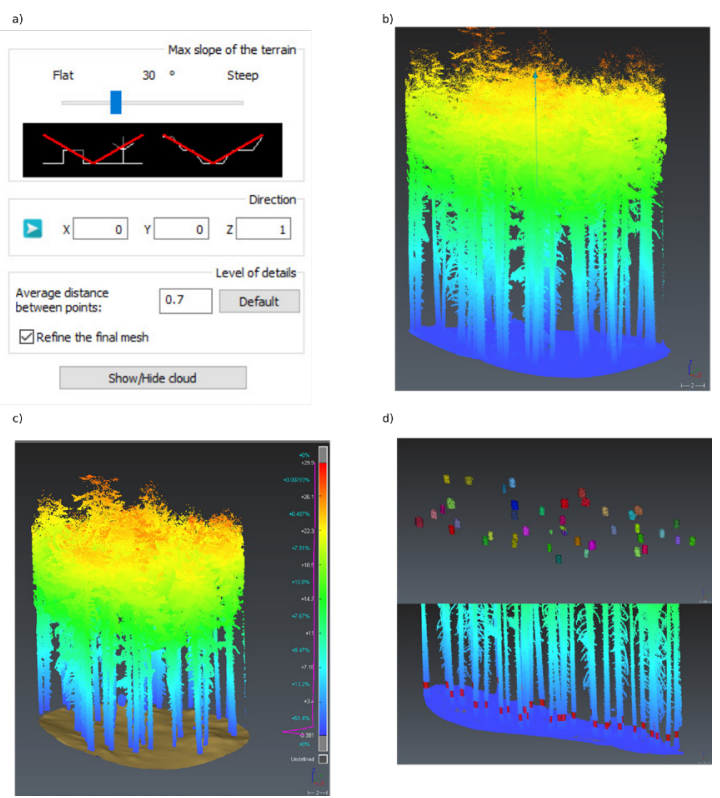

Şekil 5. a) Zemine ait noktaların sınıflandırılmasında kullanılan parametreleri, b) Örnek alan sınırlarından kesilmiş nokta bulutu, c) Zemin noktalarına göre üretilen yüzey modeli ve vejetasyon noktalar1, d)

$\mathrm{d}_{1,30}$ 'dan kesit alınmış nokta bulutu ve buradaki gövdelere ait noktalar.

Figure 5. a) Adaptive parameters for ground point classification, b) Point cloud extracted by plot borders, c) Topographic mesh model and vegetation points, d) Cross-sectioned point cloud and existed stem points. 


\subsubsection{Ağaç konumlarının kestirimi}

Ağaç konumları zeminden 1,00-1,60 m aralığında alınan kesit üzerine uygulanan silindir oturtma işlemine göre yapılmıştır (Şekil 6). En küçük kareler (EKK) algoritmasına (Lukács ve ark., 1997) göre yapılan uygulama sonrasında, silindir merkezlerinin ilgili ağaç gövdelerinin merkezini temsil ettiği varsayılmıştır ve haritalama buna göre yapılmıştır. Yoğun diri örtü, çalı gibi parazit (noise) sorunu bulunmayan örnek alanlara ait nokta bulutlarında silindire alternatif olarak daire oturtma işlemi de yapilabilmektedir. Bu durumda nokta bulutunun 1,28-1,33 m gibi daha ince dilimler halinde kesilmesi gerekir. Burada dikkat edilecek temel husus; kesit kalınlığı ne olursa olsun, kesitin orta yüksekliğinin göğüs yüksekliğine eşit olması zorunluluğudur. Çünkü Türkiye'deki orman envanteri sisteminde ağaçların göğüs çapı, insanın ort. göğüs yüksekliği olarak kabul edilen yerden 1,30 m yükseklikten ölçülmektedir (Kayacan ve ark., 2016; OGM, 2017).

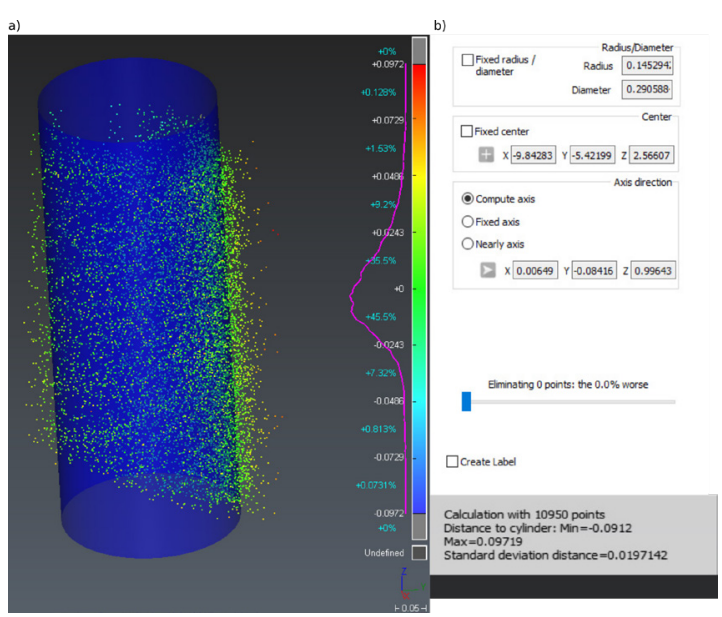

Şekil 6. a) Gövde kesitlerine silindir oturtma işlemi: gövdeye ait nokta bulutu, b) Oturtulan silindire ait çeșitli parametreler.

Figure 6. a) Cylinder fitting on a stem section: point cloud of a stem, b) Various parameters of the cylinder.

\subsubsection{Yerüstü noktaların gövde ve gövde dışı olarak sınıflandırılması}

Ağaç gövdelerine ait noktaların gövdeye ait olmayan noktalardan (dal, yaprak, çalı vb.) ayrılması için, belirlenen her ağaç konumuna ait $25 \mathrm{~cm}$ yarıçaplı sütunlar oluşturulmuştur. Belirlenen sütunlara ağaç numaraları (TreeID) atanmıştır. Meşcere parametrelerinin çıkarılabilmesi için nokta bulutlarında gövdelerin tespit edilmesi gerekmektedir. $\mathrm{Bu}$ amaçla gövde noktaları Hough daire çıkarım1na göre kestirilmiştir (Illingworth ve Kittler, 1987).
Hough dönüşümü, raster veri kümeleri üzerinde geometrik şekilleri tespit edebilen bir tekniktir (Illingworth ve Kittler, 1987). Bu araştırma çalışmasında, nokta bulutlarının iki boyutlu yatay katmanları üzerinde dairesel şekiller bulmak için bu algoritma kullanılmıştır. Her bir gövdeye ait nokta bulutu alınarak, önce her 0,5 m'de bir 1-2 m aralığında dipten tepeye doğru kesitler alınmıştır. Her kesitte, zemine dik doğrultuda bir segment oluşturulmuştur. Buradaki z ekseni vektörel olarak $[0,0,1]$ şeklinde ifade edilir. Kestirilen daire parametreleri üzerinden Hough dönüşümü uygulanarak merkez koordinatları $(\mathrm{x}, \mathrm{y})$ ve göğüs çapları elde edilmiştir. Son olarak, çap değerlerinin daha doğru çıkarılabilmesi için RANSAC (de Conto ve ark., 2017; Schnabel ve ark., 2007) temelli silindir oturtma işlemi ile optimizasyon yapılmıştır.

\subsection{Meşcere parametrelerine ilişkin değerlerin ölçüm ve hesaplanması}

\subsubsection{Göğüs çapı $\left(d_{1,30}\right)$}

LiDAR verisinde göğüs yüksekliğindeki çap $\left(\mathrm{d}_{1,30}\right)$; ağacın yerle birleştiği konumdan 1,30 m yükseklikte bulunan noktalar üzerinden hesaplanmaktadır. Eğimin \%0 olduğu, yani tamamen düz bir arazide gögüs yüksekliğinin belirlenmesi için verideki en alçak nokta baz alınmalıdır. Ancak, Artvin'deki ormanlar genellikle yüksek eğimli ve kırıklı arazilerde yer aldığı için bu yaklaşım hataya sebep olabilmektedir. Bu nedenle, öncelikle arazinin normalizasyonu gerçekleştirilmelidir. Normalizasyon işleminde, her bir ağaca en yakın zemin seviyesinden yararlanılmıştır. Böylece, hem ağaç boyları hem de göğüs çapları gerçeğe daha yakın hesaplanmıştır.

Örnek alan kolay ya da orta zorluk seviyesinde ise 3B nokta bulutu, çeşitli algoritmalar yardımıyla tek ağaç düzeyinde sınıflandırılabilmektedir. Zor örnek alanlarda ise tam otomatize yöntemler genellikle işe yaramamakta ve hatalı sonuçlar üretmektedir (Zeybek ve Vatandaşlar, 2021). Araştırmada bunun yerine, 3DReshaper programinda manuel veri analizi tercih edilmiştir. Bu noktada yarı otomatik sistemler de uygulanabilmektedir (Vatandaşlar ve Zeybek, 2021). Ağaca ait noktaların konumlarının bilinmesi, sınıflandırma algoritmalarının doğruluğunu da artırmaktadır.

Yalnızca ağaç gövdelerinin sınıflandırılması göğüs çapı ve ağaç boylarının hesaplanması için yeterlidir. Zor örnek alanlarda gövdeye ait noktalardan $60 \mathrm{~cm}$ kalınlığında kesitler alınarak, bu noktalara silindir oturtma uygulaması yapılmıştır. Kolay ve orta zorluktaki örnek alanlarda ise tekil gövdeler net olarak görülüyorsa $5 \mathrm{~cm}$ 'lik kesitlere daire doğ- 
rudan oturtulmuştur. Eğer ağaçlar eksantrik gövdelere sahip ise elips oturtma uygulaması gerçekleştirilmiştir. Böylece, gögüus çapları daha doğru şekilde hesaplanabilmektedir.

\subsubsection{Meşcere üst boyu $\left(h_{\text {üst }}\right)$}

Örnek alanlar meşcere tipleri itibariyle grupland1r1lıp üst boylarının ortalaması alınarak meşcere üst boyu hesaplanabilmektedir. Tekil ağaçların boyu ve meşcere üst boy bilgisi, orman envanterinin ötesinde hacimlendirme, yetişme ortamı verim gücünün (bonitet) saptanması ve boylanma eğrisinin çizimi gibi hasılat çalışmalarında da sıklıkla kullanılmaktadır (Eraslan, 1982; Kalıpsız, 1984).

Bu çalışmada örnek alanlarda ağaç numarası (TreeID) atanan her bir ağaca ait boy bilgisi maksimum 15 noktada z (yükseklik) değerlerine göre medyan fonksiyonu uygulanarak tespit edilmiştir. Örnek alan içerisindeki en boylu ağacın (hakim ağaç boyu), örnek alanın üst boyu olduğu varsayılmıştır.

\subsubsection{Meşcere hacmi (V)}

Hektardaki meşcere hacmini hesaplayabilmek için öncelikle örnek alanlardaki tüm ağaçların dikili haldeki kabuklu gövde hacimlerinin hesaplanması gerekir. Bunun için LiDAR verisinde gövdeyi temsil eden noktalara silindir oturtma işlemi gerçekleştirilmiştir. Tek ağaçlar için 0,50 m'lik seksiyonlar (kesit) üzerine ayrı silindirler oturtularak, her bir seksiyonun hacim değeri hesaplanmış ve toplanmıştır. Böylelikle tüm gövdenin kabuklu hacmi bulunmuştur. Bazı gövdelerin üst kısmı tepe tacı nedeniyle nokta bulutu verisinde net olarak çıkmamaktadır (Şekil 2). Bu tür ağaçların belirli bir yükseklikten sonraki gövde profilleri, çap düşüşüne göre robust doğrusal regresyon modeli yardımıyla çıkarılmıştır. Bu kapsamda, robust regresyon ile çap ve yükseklik arasındaki ilişkiden yararlanılmıştır.

$\mathrm{R}$ programında bulunan MASS paketindeki $\mathrm{rlm}$ komutu, robust regresyonun çeşitli versiyonlarını uygulamaktadır. Bu çalışmada, Huber ağırlıklı Mtahmini kullanılmıştır (Venables ve Ripley, 2002).

\subsubsection{Tek ağaçta gövde hacmi (v)}

LiDAR verisi ve arazide ölçülen çaplar üzerinden hesaplanan meşcere hacim değerleri arasındaki muhtemel farklılıkların hangi veri setinden kaynaklandığını anlayabilmek için arazide 6 adet ağaç kestirilmiştir (Şekil 7a). LiDAR cihazı ile taranan örnek ağaçlar, bu işlem sonrasında kesilerek devrilmiştir. Devrilen bu ağaçlar 2 m'lik seksiyonlara ayrılarak ölçülmüş ve Huber'in orta yüzey formülü uyarınca hacimlendirilmiştir (Şekil 7b). Seksiyon yönteminde ağacın dip kütük kısmının ve seksi- yonlarının silindirik, uç kısmın ise konik şekilde olduğu varsayılmıştır ve hacim hesapları buna göre yapılmıştır. Seksiyon yöntemi ve Huber formülüne ait eşitlikler aşağıda sırasıyla gösterilmektedir;

$V_{\text {top }}=V_{\text {dip }}+V_{\text {sek }}+V_{u \varsigma}$

$V=(\pi / 4) \times\left(d_{0,5}\right)^{2} \times l$

Eşitlik (1)'deki $V_{\text {too }}$; tüm ağaç gövdesine ait kabuklu toplam hacmi $\left(\mathrm{m}^{3}\right), V_{d i p}$; ağacın dip kütüğüne ait kabuklu hacmi $\left(\mathrm{m}^{3}\right), V_{\text {sek }}$; ağacın tüm seksiyonları için hesaplanmış kabuklu hacim toplamını $\left(\mathrm{m}^{3}\right), V_{u c}$ ise; ağacın tepe uç kısmının kabuklu hacmini $\left(\mathrm{m}^{3}\right)$ ifade etmektedir.

Eşitlik (2)'deki $V$; kabuklu gövde (seksiyon) hacmi $\left(\mathrm{m}^{3}\right), d_{0,5}$; seksiyonların orta (1 m'deki) çapı (m), l ise; seksiyon uzunluğunu (2 m) ifade etmektedir.

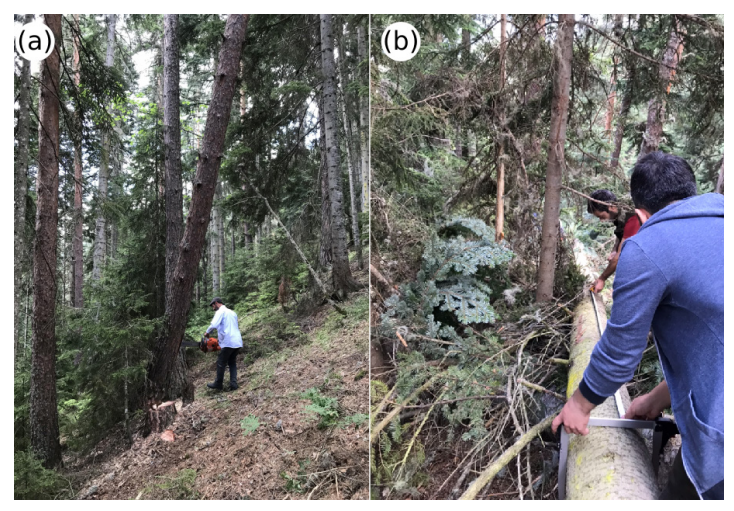

Şekil 7. a) Sahara OİŞ’nde araştırma için kesilen bir örnek ağaç, b) Devrilen ağacın seksiyon yöntemine göre hacimlendirilmesi.

Figure 7. a) Sample tree in the Sahara Forest Chiefdom,

b) Volume measurements on a felled tree with the section method.

\subsubsection{Kapalılık}

Ağaçların tepe tacı kapalılığının belirlenmesi için öncelikle nokta bulutunun hangi yükseklikten kesilmesi gerektiğine karar verilmelidir. Bu araştırma çalışmasında meşcere orta boyları göz önünde bulundurularak tüm nokta bulutlarının 10 m yükseklikten kesilmesine karar verilmiştir. Daha sonra 10 m yükseklikten kesilen nokta bulutları üzerinden kanopi (tepe tacı) modelleri üretilmiştir.

Nokta bulutlarının raster modele çevrilmesi için farklı yöntemler bulunmaktadır. Bu araştırmada watershed segmentation yöntemi kullanılmıştır (Beucher ve Lantuejoul, 1979). Eğer raster model üzerinde veri boşlukları (taranmayan alanlar) bulunuyorsa, bu alanların düzeltilmesi için kayan yüzeyler yumuşatma algoritması ve $N A$ doldurucu 
fonksiyonları kullanılmıştır (örn. Gauss kayan yüzeyler filtrelemesi). Bunun için $\mathrm{R}$ raster paketinde (Hijmans, 2021) yer alan focal fonksiyonu kullanılmıştır. Bu fonksiyon, odak hücrelerinin çevresindeki hücreler için bir ağırlık matrisi kullanma esasına dayalıdır. Ağırlıklandırma için medyan fonksiyonu uygulanmıştır. Daha sonra raster modelde elde edilmiş taç genişlikleri vektörel veriye (poligon) dönüştürülerek tepe taçlarına ait alanlar poligon olarak temsil edilmiştir. Son olarak poligonların toplam alanı, örnek alan büyüklüğüne bölünmüş ve kapalılık değeri yüzde cinsinden hesaplanmıştır.

\section{6. İstatistik analizler}

Aynı örnek ağaçlardan farklı yöntemlerle (LiDAR ve çap ölçer) elde edilen göğüs çap1 değerlerinin normal dağılım ve varyans homojenliği gibi önkoşulları sağlayıp sağlamadığı sırasıyla Kolmogorov-Smirnov ve Levene testleri ile belirlenmiştir. Daha sonra, söz konusu veri setleri arasında istatistik olarak anlamlı bir fark olup olmadığı test edilmiştir. İstatistik önkoşulların sağlandığı örnek alanlar için eşleştirilmiş t testi uygulanmıştır. Önkoşulları karşılamayan örnek alanlarda ise, bu testin parametrik olmayan karşılı̆̆ tercih edilmiştir. Sonuçlar, \%95 güven düzeyinde raporlanmıştır.

\section{Bulgular}

\subsection{Meşcere parametreleri}

\subsubsection{Ağaç konumları ve göğüs çapı}

LiDAR cihazıyla taranan örnek alanlardaki ağaçların gögüus çapındaki gövde kesitleri Şekil 8'de gösterilmektedir. Şekildeki ağaçların her biri daire şeklinde temsil edilmektedir. Dairelerin büyüklüğü $d_{130}$ göğüs çap1 değerlerine göre oransal olarak ölçeklendirilmiştir.

Daire ortasındaki noktalar, ağaç merkezlerini ifade etmektedir. Yine daire şekilli örnek alan ortasındaki kırmızı renkli üçgen ise örnek alan merkezini (kazık) göstermektedir. LiDAR verisi rölatif koordinat sisteminde olduğundan, ağaçların birbirine uzaklıkları, merkez kazığa olan mesafeleri ve kazığa göre kuzeyle yaptıkları semt açısı otomatik olarak raporlanabilmektedir.

Tablo 1, tek ağaç bazında incelendiğinde, LiDAR verisi ve arazide ölçülen çap değerleri arasındaki farkların genellikle $1 \mathrm{~cm}$ 'nin altında olduğu anlaşılmaktadır. Örnek alan bazındaki ortalamalar üzerinden karşılaştırma yapıldığında ise, iki veri seti arasındaki en yüksek farklılığın 91 numaralı Çscd2 meşceresinde $1,9 \mathrm{~cm}$ olarak hesaplandığ görülmüştür. Diğer bir ifadeyle, LiDAR yöntemi bu örnek alandaki ort. çap değerini arazi ölçümlerine nazaran \%5,5 oranında yüksek hesaplanmıştır. 50, 90 ve 142 numaralı örnek alanlardaki ort. farklar ise sirasıyla; +\%3,1, $-\% 1,2$ ve $+\% 1,4$ 'tür.

Gerçekleştirilen istatistik analizler sonucunda, LiDAR verisi ve kumpasla ölçülen çap değerleri arasında anlamlı bir fark bulunmadığı tespit edilmiştir ( $\mathrm{p}>0,05) .50$ numaralı örnek alan için uygulanan eşleştirilmiş t testinin $p$ değeri 0,239'dur. 90, 91 ve 142 numaralı örnek alanlarda ise Wilcoxon testi uygulanmış ve p değerleri sırasıyla; $0,311,0,784$ ve 0,217 bulunmuştur.
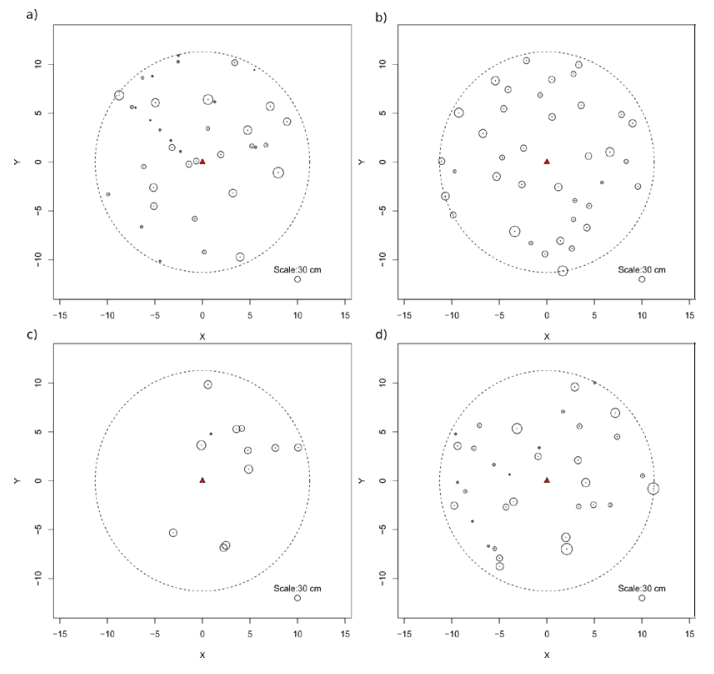

Şekil 8. Örnek alanlardaki ağaçların konumsal dağılışını gösteren haritalar: a) 50 no.lu örnek alan, b) 90 no.lu örnek alan, c) 91 no.lu örnek alan, d) 142 no.lu örnek alan. Gövde enkesitleri kendi çap genişliklerine göre ölçeklendirilmiştir.

Figure 8. Tree positions in sample plots: a) Sample plot 50, b) Sample plot 90, c) Sample plot 91, d) Sample plot 142. Stem sections were scaled according to their DBHs.

Örnek alanlardaki ağaçlarda LiDAR ve yersel ölçümle tespit edilen çap değerleri arasındaki uyumu daha iyi analiz edebilmek için dağılım grafikleri çizdirilmiştir (Şekil 9). Şekil 9 incelendiğinde, tüm örnek alanlarda iki veri seti arasındaki uyumun oldukça yüksek olduğu anlaşılmaktadır. LiDAR ve çapölçer ile ölçülen değerler doğrusal regresyon yöntemiyle modellendiğinde, örnek alanlardaki belirtme katsayılarının $\left(\mathrm{R}^{2}\right)$ \%98,6 ve \%99,2 aralığında olduğu görülmüştür. Bu kadar yüksek olan $\mathrm{R}^{2}$ değerleri, iki veri seti arasındaki korelasyonun pozitif yönde ve çok kuvvetli olduğunu göstermektedir.

\subsubsection{Ağaç sayısı (N)}

Tablo 1'de ayrıca örnek alanlardaki toplam ağaç sayısı da görülmektedir. Örnek alan büyüklükleri 
Tablo 1. Örnek alanlardaki ağaçların LiDAR ve çapölçer ile ölçülmüş göğüs çaplar1. Table 1. Tree DBHs measured by LiDAR and caliper in sample plots.

\begin{tabular}{|c|c|c|c|c|c|c|c|c|}
\hline \multirow{3}{*}{$\begin{array}{c}\text { Ağaç } \\
\text { no. }\end{array}$} & \multicolumn{8}{|c|}{ Örnek alanların numarası ve meşcere tipi rumuzu } \\
\hline & \multicolumn{2}{|c|}{50 (LÇscd3) } & \multicolumn{2}{|c|}{$90(\mathrm{GLcd} 3)$} & \multicolumn{2}{|c|}{$91($ Çscd2) } & \multicolumn{2}{|c|}{$142(\mathrm{LÇscd} 3)$} \\
\hline & $\begin{array}{l}\text { Lidar-çap } \\
\quad(\mathrm{cm})\end{array}$ & $\begin{array}{l}\text { Karne-çap } \\
\quad(\mathrm{cm})\end{array}$ & $\begin{array}{l}\text { Lidar-çap } \\
\quad(\mathrm{cm})\end{array}$ & $\begin{array}{l}\text { Karne-çap } \\
\quad(\mathrm{cm})\end{array}$ & $\begin{array}{l}\text { Lidar-çap } \\
\quad(\mathrm{cm})\end{array}$ & $\begin{array}{l}\text { Karne-çap } \\
\quad(\mathrm{cm})\end{array}$ & $\begin{array}{l}\text { Lidar-çap } \\
\quad(\mathrm{cm})\end{array}$ & $\begin{array}{l}\text { Karne-çap } \\
\quad(\mathrm{cm})\end{array}$ \\
\hline 1 & 12,0 & 11,9 & 30,5 & 31,0 & 46,0 & 45,4 & 33,5 & 33,0 \\
\hline 2 & 19,0 & 20,1 & 54,0 & 51,5 & 10,9 & 11,0 & 38,2 & 37,8 \\
\hline 3 & 9,2 & 8,6 & 16,7 & - & 40,0 & 41,5 & 12,6 & 12,5 \\
\hline 4 & 15,4 & 16,1 & 18,8 & 18,6 & - & 13,0 & 39,2 & 41,0 \\
\hline 5 & 22,7 & 23,7 & 30,3 & 30,2 & 37,2 & 37,7 & 30,9 & 30,7 \\
\hline 6 & 32,5 & - & 33,9 & 34,2 & 30,0 & 29,7 & 31,4 & 32,2 \\
\hline 7 & 50,3 & 50,7 & 36,7 & 37,5 & 34,2 & 32,7 & 12,4 & 12,4 \\
\hline 8 & 43,1 & 42,4 & 23,1 & 23,4 & 42,2 & 42,2 & 19,5 & 20,8 \\
\hline 9 & 13,1 & 12,8 & 27,3 & 27,8 & 35,4 & 34,3 & 10,8 & 10,5 \\
\hline 10 & 21,6 & 22,2 & 26,6 & 27,0 & 36,8 & 35,0 & 36,6 & 36,0 \\
\hline 11 & 20,4 & 22,1 & 50,8 & 48,0 & 41,2 & 42,0 & 19,4 & 18,0 \\
\hline 12 & 54,1 & - & 21,1 & 18,7 & 39,7 & 40,5 & 12,1 & 12,3 \\
\hline 13 & 37,8 & 37,6 & 14,6 & 15,5 & 38,2 & 38,6 & 23,6 & 24,2 \\
\hline 14 & 42,6 & 41,8 & 33,7 & 33,8 & - & - & 14,5 & 14,0 \\
\hline 15 & 10,9 & 10,3 & 29,1 & 28,9 & - & - & 22,4 & 23,5 \\
\hline 16 & 13,7 & 13,2 & 38,5 & 38,6 & - & - & 51,1 & 49,0 \\
\hline 17 & 11,0 & 11,7 & 34,2 & 36,4 & - & - & 26,1 & 25,3 \\
\hline 18 & 41,3 & 39,6 & 33,8 & 34,2 & - & - & 47,1 & 48,0 \\
\hline 19 & 8,0 & 8,5 & 44,7 & 44,0 & - & - & 12,0 & 11,7 \\
\hline 20 & 16,3 & 16,6 & 40,6 & 40,8 & - & - & 27,4 & 26,8 \\
\hline 21 & 11,0 & 10,5 & 39,8 & 39,6 & - & - & 20,4 & 21,5 \\
\hline 22 & 34,8 & 35,0 & 21,4 & 22,0 & - & - & 43,2 & 41,6 \\
\hline 23 & 13,9 & 15,1 & 37,2 & 38,2 & - & - & 29,7 & 28,1 \\
\hline 24 & 16,5 & 17,0 & 31,1 & 31,0 & - & - & 23,9 & 24,3 \\
\hline 25 & 47,5 & 49,7 & 26,5 & 26,4 & - & - & 57,8 & 51,3 \\
\hline 26 & 31,7 & 33,2 & 33,6 & 33,7 & - & - & 37,2 & 36,8 \\
\hline 27 & 10,4 & 8,6 & 33,0 & 33,5 & - & - & 11,7 & 11,5 \\
\hline 28 & 20,0 & 21,4 & 24,1 & 24,8 & - & - & 8,0 & 8,3 \\
\hline 29 & 39,7 & 38,3 & 46,7 & 44,2 & - & - & 16,0 & 15,5 \\
\hline 30 & 29,4 & 30,5 & 32,1 & 32,0 & - & - & 41,2 & 41,2 \\
\hline 31 & 11,0 & 10,8 & 32,4 & 32,5 & - & - & 35,9 & 36,0 \\
\hline 32 & 31,1 & 32,8 & 32,9 & 33,3 & - & - & 21,2 & 22,2 \\
\hline 33 & 30,5 & 32,5 & 42,5 & 41,6 & - & - & 58,5 & 55,0 \\
\hline 34 & 42,2 & 39,6 & 40,9 & 41,1 & - & - & 43,6 & 42,5 \\
\hline 35 & 25,2 & 27,4 & 26,0 & 25,8 & - & - & - & - \\
\hline 36 & 39,8 & 39,1 & 33,9 & 34,3 & - & - & - & - \\
\hline 37 & - & - & 32,0 & 31,5 & - & - & - & - \\
\hline 38 & - & - & 34,0 & 36,0 & - & - & - & - \\
\hline Ort. & 25,8 & 25,0 & 32,6 & 33,0 & 36,0 & 34,1 & 28,5 & 28,1 \\
\hline
\end{tabular}


farklı olduğu için (örn. 91 no.lu örnek alan $600 \mathrm{~m}^{2}$, diğerleri $400 \mathrm{~m}^{2}$ ) tüm örnek alanlar hektara çevrilerek birim alandaki ağaç sayıları bulunmuştur.

50, 90, 91 ve 142 numaralı örnek alanlarda LiDAR verisi üzerinden tespit edilen ağaç sayılarının hektara çevirme katsayısıyla çarpılması suretiyle hesaplanan birim alandaki ağaç sayıları sırasıyla; 900 $\mathrm{ad} / \mathrm{ha}, 950 \mathrm{ad} / \mathrm{ha}, 199 \mathrm{ad} / \mathrm{ha}$ ve $850 \mathrm{ad} / \mathrm{ha}$ 'dır. Aynı alanlarda arazide tespit edilen ağaç sayıları ise; 850 $\mathrm{ad} / \mathrm{ha}, 925 \mathrm{ad} / \mathrm{ha}, 216 \mathrm{ad} / \mathrm{ha}$ ve $850 \mathrm{ad} / \mathrm{ha}$ 'dır. İki veri seti arasındaki en büyük farklılık 50 numaralı örnek alanda bulunmuştur: LiDAR yöntemi ile örnek alanda farklı ölçülen 2 adet ağaç, alan hektara dönüştürüldüğünde toplamda 50 adet ağaç olarak hesaplanmaktadır. 142 numaralı örnek alandaki ağaçlar ise her iki veri setinde de tam olarak aynı bulunmuştur.
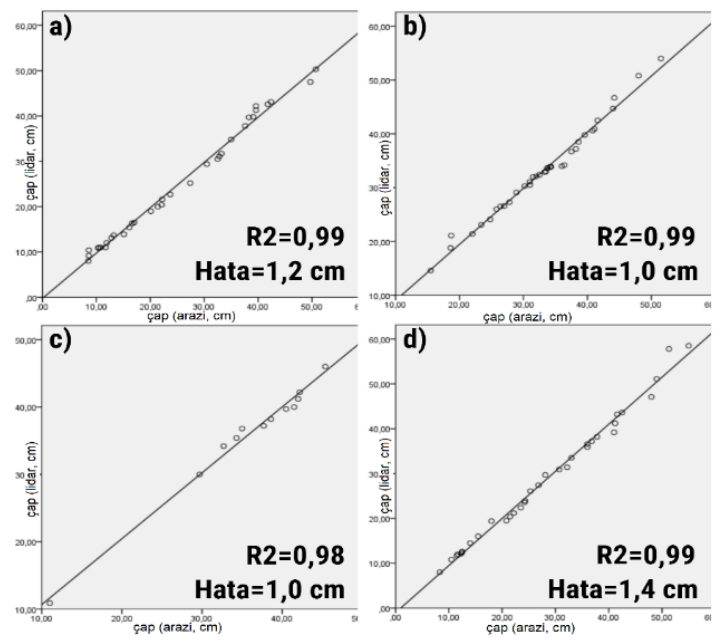

Şekil 9. Örnek alanlarda LiDAR cihazı ve çapölçer ile ölçülen göğüs çaplarının dağılım grafikleri: a) 50 no.lu örnek alan, b) 90 no.lu örnek alan, c) 91 no.lu örnek alan, d) 142 no.lu örnek alan.

Figure 9. Scatter plots of the ground and LiDARderived DBHs: a) Sample plot 50, b) Sample plot 90, c) Sample plot 91, d) Sample plot 142.

Bazı örnek alanlardaki ağaç sayıları arasındaki uyumsuzlukların genellikle sınır ağaçları ya da 8 cm'ye yakın çaplı ince ağaçlardan kaynakladığı anlaşılmıştır. Arazide merkez kazıktan ip çekilerek tespit edilen örnek alan sınırları, LiDAR verisinde merkez noktadan (x:0, y:0, z:0) daire yarıçapı (400 $\mathrm{m}^{2}$ için 11,28 m) girilip kesilerek tespit edilmektedir. Dolayısıyla sınıra yakın bazı ağaçlardan gövdesinin yarısı içeride kalan bir fert, LiDAR yönteminde otomatik olarak analize dahil edilmektedir. Benzer şekilde, arazide göğüs çapı 7,9 cm olarak ölçülen bir diğer ağaç envanter karnesine kaydedilmez iken, aynı ağaç LiDAR verisinde 8,0 cm olarak ölçüldüyse analize dahil edilmekte ve buna benzer nedenlerle ağaç sayıları arasında küçük farklar oluşabilmektedir. Son olarak, bazı örnek alanlardaki ikiz ya da çatallı gövdeler de LiDAR verisinde tek bir ağaçmış gibi algılanabilmekte ve dolayısıyla örnek alandaki toplam ağaç sayısında eksi yönde farklılık çıkabilmektedir.

\subsubsection{Meşcere üst boyu $\left(h_{\text {üst }}\right)$}

Her bir örnek alandaki hakim (en boylu) ağaç boyları Tablo 2'de gösterilmiştir. Tablo 2 incelendiğinde, hem LiDAR verisi hem de yersel ölçümler sonucunda en yüksek üst boya sahip örnek alanın 90 numaralı GLcd3 meşceresi olduğu görülmüştür. LiDAR cihazı buradaki hakim ağaç boyunu yersel ölçüme göre 1,9 m daha düşük ölçmüştür. Bu farkl1l1k $30 \mathrm{~m}$ gibi oldukça boylu bir meşcere tipinde eksi yönde \%6,3'lük bir sapmaya karşılık gelmektedir. LiDAR ile daha düşük boy tespitinin nedeni; söz konusu meşcerenin çok sık ve katlı oluşuyla ilgili olabilir. Nitekim, buradaki karışık meşcere grift kapalı (>\%100) olup ağaç serveti $1000 \mathrm{~m}^{3} / \mathrm{ha}$ civarındadır. Bu tip yoğun ve grift meşcerelerde iç içe geçmiş tepe taçları ya da birbirini örten tepeler, zaman zaman hakim ağacın tepe ucunun görülmesini engelleyebilmektedir (Jurjević ve ark., 2020).

Diğer örnek alanlar incelendiğinde, üst boy verilerindeki farklılıkların LiDAR lehine olduğu anlaşılmaktadır. En yüksek fark, 142 numaralı LÇscd3 meşceresinde $+2,5 \mathrm{~m}$ olarak çıkmıştır. $\mathrm{Bu}$ tip farklılıkların arazi ölçümlerindeki hatalardan da kaynaklanabileceği değerlendirilmiştir. Nitekim, özellikle grift meşcerelerde ve zor örnek alanlarda, dijital boyölçer ile en boylu ağacın tepe ucuna rasat yapabilmek her zaman mümkün olmamaktadır. Böyle durumlarda teknik elemanlar (orman müh.) meşcereyi temsil eden ve etrafı açık olan diğer boylu ağaçlarda boy ölçümü yapıp envanter karnesine kaydedebilmektedirler. İki veri seti arasındaki farkl1lıkların bir nedeni de bu olabilir. Sonuç itibariyle, dört örnek alanın ortalamalarına bakılırsa, veri setleri arasındaki farkın 0,8 m'ye kadar düştüğü görülebilir (Tablo 2). Bu fark, art1 yönde \%3,4'e karşılık gelmektedir.

\subsubsection{Meşcere hacmi (V)}

LiDAR ile taranan dikili ağaç gövdeleri 3B nokta bulutu verileri üzerinden bütün olarak çıkarılmış, hacimlendirilmiş ve Amenajman Plan Programı (APP) yazılımındaki dikili kabuklu ağaç hacim tabloları üzerinden hesaplanan (tek girişli) hacim değerleriyle karşılaştırılmıştır. İki veri seti arasındaki farklar örnek alan (karne) bazında hektara çevirme katsayısıyla çarpılarak Tablo 2'de raporlanmıştır. 
Tablo 2. Örnek alanların LiDAR ve yersel ölçümlere dayalı olarak hesaplanmıș üst boy ve meșcere hacimleri.

Table 2. Top heights and stand volumes calculated by LiDAR and ground measurement methods.

\begin{tabular}{|c|c|c|c|c|c|c|}
\hline $\begin{array}{c}\text { Örnek alan } \\
\text { no. }\end{array}$ & $\begin{array}{l}\text { Lidar-üstboy } \\
\text { (m) }\end{array}$ & $\begin{array}{c}\text { Karne-üstboy } \\
\text { (m) }\end{array}$ & Fark & $\begin{array}{l}\text { Lidar-meşcere } \\
\text { hacmi }\left(\mathrm{m}^{3} / \mathrm{ha}\right)\end{array}$ & 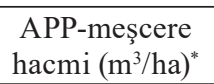 & Fark \\
\hline 50 & 27,0 & 24,8 & $+\% 8,9$ & 778,0 & 562,0 & $+\% 38,4$ \\
\hline 90 & 28,1 & 30,0 & $-\% 6,3$ & 1323,0 & 999,0 & $+\% 32,4$ \\
\hline 91 & 15,3 & 15,0 & $+\% 2,0$ & 145,0 & 221,0 & $-\% 34,4$ \\
\hline 142 & 27,5 & 25,0 & $+\% 10,0$ & 908,0 & 749,0 & $+\% 21,2$ \\
\hline Ort. & 24,5 & 23,7 & $+\% 3,4$ & 788,5 & 632,8 & $+\% 24,6$ \\
\hline
\end{tabular}

(*) Amenajman plan programında (APP) yer alan yöresel tek girişli ağaç hacim tabloları yardımıyla göğüs çapı üzerinden hesaplanan hektardaki hacim değerleridir

Tablo 2 bir bütün olarak incelendiğinde, 91 numaralı alan hariç diğer üç örnek alanda LiDAR ile hesaplanan hacimlerin APP'deki hacim değerlerinden daha yüksek olduğu görülmüștür. Örneğin, 90 numaralı GLcd3 meşceresinin hacmi, hacim tablosu üzerinden ölçülenden $\% 32,4$ civarında daha yüksek bulunmuştur. Bunun nedeni; söz konusu meşcerenin oldukça boylu oluşu ( $30 \mathrm{~m}$ ), orta ağaçlık çağına (36-52 cm) yaklaşmış olması, çok iyi bonitetli sahada yer alması ve gövde formlarındaki anomaliler olabilir. Nitekim, APP'de yer alan hacim değerleri, geçmişte o yöre için ağaç türü itibariyle ort. bonitete göre düzenlenmiş tek girişli dikili kabuklu gövde hacim tablolarından türetilmektedir. Bu tablolar ağaçların boyu ve gövde formunu dikkate almadan yalnızca çap kademeleri üzerinden hacimlendirme yapmaktadır. Çap değerleri 4 cm'lik kademelere girilerek hacim bulunmaktadır. Bir başka ifadeyle, $32,0 \mathrm{~cm}$ ve $35,9 \mathrm{~cm}$ çaplarındaki iki ağacın hacmi aynı hesaplanmaktadır. Buna karşılık, LiDAR nokta bulutları üzerinden 3B hacimlendirilen gövdelerin hem çapı hem boyu hem de gövde formu ayrı birer faktör olarak hesaba katılmaktadır. Bu anlamda, LiDAR ile hesaplanan hacimlerin daha güvenilir olacağı söylenebilir.

Diğer örnek alanların farklı yöntemlerle hesaplanan meşcere hacimleri arasında da önemli farkl1lıklar görülmüștür (Tablo 2). Dört örnek alanın ort. değerlerine bakıldığında, iki veri seti arasındaki farklılık LiDAR lehine artı yönde \%24,6'dır. Tablo 2'de 91 numaralı örnek alana ait hacim değerleri dikkat çekmektedir. Çünkü buradaki farkl1lık, diğerlerinin aksine, eksi yönlüdür. Yani LiDAR verisi üzerinden hesaplanan meșcere hacmi APP'den düşük çıkmıştır.

Bunun iki ayrı nedeni olduğu düşünülmektedir. İlk neden; düşük bonitet ile alakalı olabilir: 91 numaralı Çscd2 meşceresinin bonitetinin, çalışma alanının ort. bonitet derecesinden daha düşük olduğu değerlendirilmiştir. Araştırmada bonitet saptamaya dönük ölçümler yapılmamasına rağmen, buradaki meşcere üst boyunun $15 \mathrm{~m}$ olması ve kapalılığın \%45'e kadar düşüşü bu değerlendirmeyi desteklemektedir. Nitekim, çalışma alanındaki meşcerelerin ort. boyu yaklaşık $25 \mathrm{~m}$, kapalılığ birkaç istisna hariç hep tam kapalıdır. İkinci olas1 neden; bu örnek alanda LiDAR ile tespit edilen ağaç sayısının arazide ölçülenden eksik oluşudur. Dolayısıyla yer verisinde toplam 13 ağaç sayılmışken, LiDAR verisinde 1 ağaç eksik sayılmıştır (ya da arazide 1 ağaç fazladan sayılmıştır).

\subsubsection{Tek ağaçta gövde hacmi (v)}

Arazide ölçülen çaplara dayalı olarak ve tek girişli hacim tablosunda yerine konularak hesaplanan APP hacim değerleri mutlak doğru (referans veri) kabul edilemeyeceği için, LiDAR verisinin doğruluğunu tespit edebilmek adına ilave bir analiz daha gerçekleştirilmiştir. Yöntem bölümünde anlatıld1$\breve{g} 1$ üzere, kesilip yerde hacimlendirilen ağaçların gerçek gövde hacimleri, tek ve çift girişli hacim tablolarındaki hacimleri ve LiDAR ile hesaplanan hacimleri Tablo 3'de toplu olarak sunulmuşstur.

Tablo 3'de seksiyon yöntemine göre hesaplanan gövde hacimlerinin mutlak doğru olduğu varsayılirsa, LiDAR ile hesaplanan hacim değerleri ort. olarak art1 yönde \%5,1 sapma göstermiştir. En büyük sapma $+\% 36,0$ ile 2 numaralı ağaçta görülmüştür. Söz konusu ağacın türü göknar, göğüs çap $28,7 \mathrm{~cm}$, boyu ise 18,4 m'dir. Hacim değerleri arasındaki büyük farklılık, ağaç gövdesinin üst k1sımlarının tepe tacı tarafından örtülmesi nedeniyle LiDAR cihazı ile tam olarak tespit edilememesine dayandırılmıştır. Diğer ağaçlarda görülen artı ve eksi yönlü sapmalar $\% 1,5$ ila $\% 7,1$ arasında değişmiştir. Artı ve eksi yönlü sapmaların olması istatistik açıdan arzu edilen bir durumdur ve veri setinin yanlı olmadığını (unbiased) gösterir. Hyyppä ve ark. (2020), Qiu ve ark. (2018) ve Zeybek ve Vatandaşlar (2021), hacim parametresinde \%10'un altındaki sapma oranlarının orman amenajmanı pratiğinde kabul edilebilir nitelikte olduğunu belirtmektedirler. 
Tablo 3. Kesilen ağaçların farklı yöntemlerle hesaplanmıș kabuklu gövde hacimlerinin karşılaștırılması. Table 3. Comparison of stem volumes calculated from the felled trees using different methods.

\begin{tabular}{ccccccccc}
\hline $\begin{array}{c}\text { Örnek } \\
\text { ağaç no. }\end{array}$ & $\begin{array}{c}\text { Ağaç } \\
\text { türü }\end{array}$ & $\begin{array}{c}\text { Göğüs } \\
\text { çap1 }(\mathrm{cm})\end{array}$ & $\begin{array}{c}\text { Ağaç } \\
\text { boyu }(\mathrm{m})\end{array}$ & $\begin{array}{c}\text { LiDAR ha- } \\
\text { cim }\left(\mathrm{m}^{3}\right)^{*}\end{array}$ & $\begin{array}{c}\text { Tek girişli } \\
\text { hacim }\left(\mathrm{m}^{3}\right)^{* *}\end{array}$ & $\begin{array}{c}\text { Çift girişli } \\
\text { hacim }\left(\mathrm{m}^{3}\right)^{* * *}\end{array}$ & $\begin{array}{c}\text { Seksiyon ha- } \\
\text { cim }\left(\mathrm{m}^{3}\right)^{* * * * *}\end{array}$ & $\begin{array}{c}\text { Fark } \\
\text { h***** }\end{array}$ \\
\hline 1 & $\mathrm{G}$ & 50,7 & 31,6 & 3,451 & 2,534 & 3,079 & 3,223 & $+\% 7,1$ \\
2 & $\mathrm{G}$ & 28,7 & 18,4 & 0,831 & 0,742 & 0,596 & 0,611 & $+\% 36,0$ \\
3 & $\mathrm{~L}$ & 26,1 & 18,3 & 0,535 & 0,519 & 0,518 & 0,518 & $+\% 3,1$ \\
4 & $\mathrm{~L}$ & 19,3 & 14,6 & 0,225 & 0,216 & 0,250 & 0,232 & $-\% 3,0$ \\
5 & $\mathrm{G}$ & 35,8 & 28,8 & 1,401 & 1,022 & 1,506 & 1,423 & $-\% 1,5$ \\
6 & Çs & 33,2 & 28,7 & 1,099 & 0,876 & 1,033 & 1,166 & $-\% 5,7$ \\
\hline Ort. & & 32,3 & 23,4 & 1,257 & 0,985 & 1,164 & 1,196 & $+\% 5,1$ \\
\hline
\end{tabular}

(*) LiDAR nokta bulutu üzerinden tek ağaç bazında 3B yüzey modeli ile hesaplanan dikili kabuklu gövde hacmi, (**) Amenajman planındaki tek girişli yöresel hacim tablosu ile göğüs çapı üzerinden hesaplanan dikili kabuklu gövde hacmi, (***) Miraboğlu (1955), Alemdağ (1966) ve Akalp (1978) tarafından hazırlanmış çift girişli genel hacim tabloları ile göğ̈̈s çapı ve ağaç boyu üzerinden hesaplanan dikili kabuklu gövde hacmi, (****) Kesilen ağaçların devrik gövdeleri üzerinde seksiyon yöntemine göre hesaplanan kabuklu gövde hacmi. Bu sütundaki değerler mutlak doğru (referans) olarak kabul edilmiştir, (*****) LiDAR ile ölçülen gövde hacminin seksiyon yöntemiyle hesaplanan hacim değerinden farkı.

\subsubsection{Kapalılık}

LiDAR verisi üzerinden hesaplanan tepe tacı kapal1lıkları tüm örnek alanlarda tutarlı sonuçlar üretmiştir (Şekil 10). 50, 90, 91 ve 142 numaralı örnek alanlarının sahada tespit edilip envanter karnesine kaydedilen kapalılık sinıfları sirasıyla; 3 (tam kapa1), 3, 2 (orta kapalı) ve 3’tür. Bilindiği gibi 2 ve 3 kapalı meşcere tepe taçlarının toprağ 1 örtme oranları sırasıly; \% 40-\%70 ve \%71-\%100'dür (OGM 2017).

Şekil 10'da LiDAR ile hesaplanan kapalılık yüzdeleri de meşcere tipi rumuzlarında yer alan kapalılık sınıfı sınırları içinde yer almıştır. Dört örnek alanın tümünde LiDAR ve karne değerleri arasında uyumsuzluk yoktur. LiDAR ile hesaplanan kapal1lık yüzdelerinin hem daha hassas hem de daha objektif olduğu sonucuna ulaşılmıştır. Nitekim, sahada örnek alanlar için tespit edilen kapalılık sınıfları envanterde çalışan teknik elemanın kişisel deneyim ve gözlemlerine dayalı olarak belirlenmektedir. Özellikle kapalılık sınıfı sınırlarına yakın değerlerde (örn. \%40), bir mühendisin 2 kapalı olarak değerlendirdiği sahayı bir başka mühendis 1 kapalı olarak değerlendirebilmektedir. Bunlara ilaveten, kapalılığ LiDAR yöntemiyle tayin etmenin başka avantajları da vardır. Örneğin; örnek alan içerisindeki boşlukların konumsal dağılışı da bu yöntemle ortaya konabilmektedir (Şekil 10). Ayrıca LiDAR cihazının menzili oldukça geniş olduğundan (her yöne 100'er m), kapalılık değerlendirmelerini bölmecik bazında yapmak da mümkündür. Dolayısıyla, Orman Amenajmanı Başmühendisi ve Deneticileri nihai meşcere haritasını üretirken ortofoto ve uydu görüntüleri yanı sıra 3B nokta bulutlarından da yararlanabilirler.

\subsubsection{Asli ağaç türü ve tür karışımı}

$\mathrm{Bu}$ araştırmada, LiDAR ile üretilen nokta bulutları üzerinden ağaç türü ve meşcere tipleri belirlenememiştir. Ancak, örnek alan içindeki ağaç türleri LiDAR'a entegre kamera ile kaydedilen $4 \mathrm{~K}$ videolar üzerinden görsel yorumlamayla teşhis edilmiştir (Şekil 4c, 11). Daha sonra ağaç türü ve tür karışımlarına dayalı olarak örnek alanların meşcere tiplerine büroda karar verilmiştir. Bu işlemler sonucunda, iki veri seti arasında meşcere tipindeki ağaç türü rumuzları açısından farklılık arz eden bir örnek alana rastlanmamıştır. Ancak, videolar ile karne verisi arasında ağaç türü itibariyle tek ağaç bazında karşılaştırma yapmak mümkün olmamıştır.
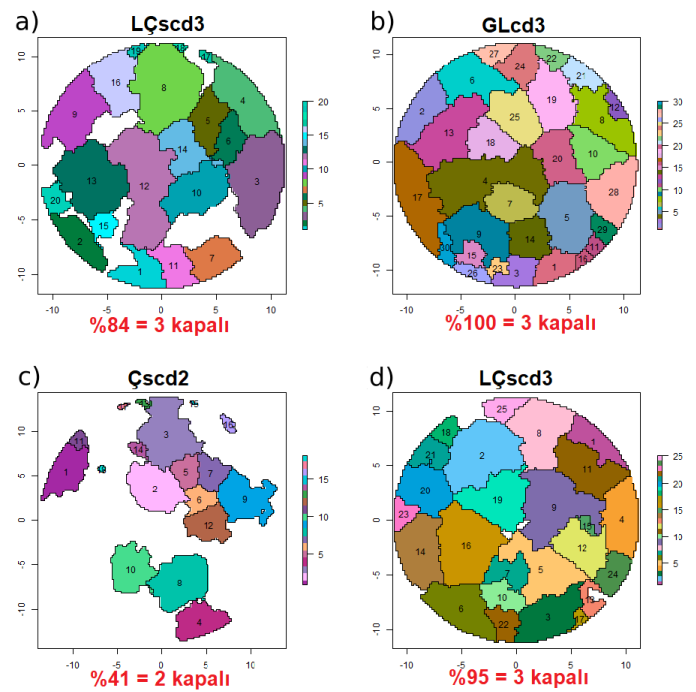

Şekil 10. Örnek alanların kuşbakışı görünümü ve LiDAR'la hesaplanan kapalılıkları: a) 50 no.lu örnek alan, b) 90 no.lu örnek alan, c) 91 no.lu örnek alan, d) 142 no.lu örnek alan.

Figure 10. Canopy closure maps of the sample plots: a) Sample plot 50, b) Sample plot 90, c) Sample plot 91, d) Sample plot 142 . 


\section{2. İşlem sürelerinin karşılaştırılması}

LiDAR verisi üzerinden yukarıda raporlanan çeşitli meşcere parametrelerine ait değerlerin çıkarımında farklı işlem adımları bulunmaktadır ve her adımın işlem süresi birbirinden farklıdır. Aynı sü- reç geleneksel envanter yöntemi için de geçerlidir. Dolayısıyla her işlem adımı zamansal olarak ayrı ayrı değerlendirilerek LiDAR ve geleneksel envanter yöntemlerinin zamansal karşılaştırması Tablo 4 'te sunulmuştur.

Tablo 4. LiDAR ve geleneksel envanter yöntemlerinin zamansal karşılaştırması.

Table 4. Temporal comparison of LiDAR and conventional forest inventory methods.

\begin{tabular}{cccccccc}
\hline $\begin{array}{c}\text { Örnek } \\
\text { alan } \\
\text { no. }\end{array}$ & \multicolumn{3}{c}{ LiDAR ile envanterde işlem süreleri (dk) } & \multicolumn{3}{c}{ Geleneksel envanterde işlem süreleri (dk) } \\
\cline { 2 - 7 } & $\begin{array}{c}\text { Veri alım1 } \\
\text { (tarama) }\end{array}$ & $\begin{array}{l}\text { Veri aktarım1 } \\
\text { ve ön işleme }\end{array}$ & $\begin{array}{c}\text { Manuel veri ana- } \\
\text { lizi ve raporlama }\end{array}$ & $\begin{array}{c}\text { Toplam } \\
\text { süre }\end{array}$ & $\begin{array}{c}\text { Alan ölçümü ve } \\
\text { karne doldurma }\end{array}$ & $\begin{array}{c}\text { APP veri girişi } \\
\text { ve raporlama }\end{array}$ & $\begin{array}{c}\text { Toplam } \\
\text { süre }\end{array}$ \\
\hline 50 & 10 & 10 & 10 & 30 & 22 & 8 & 30 \\
90 & 5 & 5 & 10 & 20 & 24 & 6 & 30 \\
91 & 5 & 5 & 10 & 20 & 20 & 4 & 24 \\
142 & 14 & 14 & 10 & 38 & 13 & 8 & 21 \\
\hline \multicolumn{7}{r}{} \\
\hline
\end{tabular}

LiDAR ile envanterde temel iş aşamaları; (i) veri alımı (tarama), (ii) veri aktarımı ve ön işleme, (iii) manuel veri analizi ve raporlama şeklindedir. Geleneksel envanter yönteminde ise iki iş aşaması vardır: (i) alan ölçümü ve karne doldurma, (ii) APP'de veri girişi ve raporlama.

Tablo 4 incelendiğinde, her iki yöntem için harcanan toplam zamanın neredeyse aynı olduğu görülmüştür. Ancak, geleneksel yöntemde geçen sürenin büyük kısmını arazi çalışmaları oluştururken, LiDAR yönteminde büro çalışmaları ağırlıktadır. Arazide geçen süre boyunca yapılan masraf (konaklama, ulaşım, harcırah vb.) ve harcanan emek göz önüne alındığında, LiDAR yönteminin eğim, diri örtü ve ağaç türü kompozisyonlarının karmaşık olmadığg sahalarda daha avantajlı olabileceği düşünülmektedir.

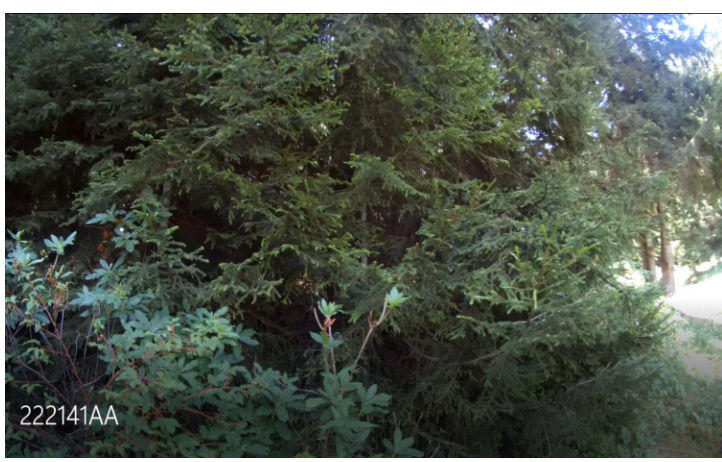

Şekil 11. 50 no.lu örnek alandaki yoğun vejetasyon ve dallanma nedeniyle nokta bulutunda gövdesi tespit edilemeyen ağaç topluluğu.

Figure 11. Trees whose stems are unable to detect on point clouds due to dense undergrowth in the sample plot 50 .
LiDAR yönteminde veri alımı 1 teknik eleman (operatör) tarafından yapilabilmektedir. Orman arazi şartlarında teknik elemanın yanında 1 işçi daha bulunması güvenlik açısından gerekli ve yeterlidir. Dolayısıyla, LiDAR yöntemiyle orman envanteri toplamda 2 eleman ile zorlanmadan gerçekleştirilebilir. Geleneksel envanter yönteminde ise 1 teknik eleman ve 2 işçi ile toplamda 3 elemana ihtiyaç duyulmaktadır. Diğer taraftan, geleneksel yöntemde arazide yanlış ya da eksik ölçüldüğü sonradan anlaşılan bir parametrenin tekrar ölçümü için yeniden aynı noktaya gidilmek zorundadır. LiDAR yönteminde ise tüm veriler dijital ortamda depolandığ 1 için daha sonra gerek duyulduğu anda ilave ölçüm ya da ek analizler büro ortamında gerçekleştirilebilir (örn. devrik ağaçların tespiti). Bu anlamda, LiDAR verileri OİPD arşivinin zaman içerisinde tamamen dijital ortama taşınmasına da hizmet edebilir.

\section{Tartışma ve Sonuç}

$\mathrm{Bu}$ araştırmanın bulguları bir bütün olarak değerlendirildiğinde, orman amenajman planlarında yer alan birçok meşcere parametresinin el tipi mobil LiDAR yöntemiyle arazide daha az vakit harcanarak ve kabul edilebilir doğruluk düzeylerinde hesaplanabildiği sonucuna ulaşılmıştır. Ancak, LiDAR yöntemiyle yapılan envanter çalışmaları boyunca farklı aşamalarda bir takım zorluklarla da karşılaşılmıştır. Çalışma alanının büyük bir bölümü Milli Park statüsünde bir korunan alan olduğu için orman oldukça bakımsız ve meşcereler çok sıktır. Bu nedenle, örnek alanlarda çok sayıda devrik, yaslanmış ağaç, diri örtü, çalı, ince çaplı mağlup gövde, iç içe girmiş tepeler ve kalitesiz gövdeler bulunmaktadır. Bu tip unsurlar, 3B Li- 
DAR verisinde bol miktarda parazite (noise) neden olmaktadır. Böyle örnek alanlarda veri analiz süreçlerine manuel (el ile) müdahaleler gerekmekte ve büro çalışmaları uzamaktadır.

Örnek alanlardaki hakim ağaç türlerinin ladin ve göknar oluşu da LiDAR verisinin analizini güçleştirmiştir. Çünkü söz konusu ağaç türleri gölgeye dayanıklı oldukları için genellikle çok katlı meşcereler oluşturmaktadır. Çok katlı meşcerelerde fark11 boydaki ağaç gövdelerini birbirinden ayırarak sınıflandırmak zorlaşmaktadır. Ayrıca bu türlerin konik yapıdaki tepe taçları zaman zaman yere kadar inmekte ve gövdenin görülmesini engellemektedir (Şekil 11).

Şekil 11'de gösterilen koşullara sahip sahalar, LiDAR yönteminin etkili şekilde uygulanabilmesi için literatürde "zor örnek alan" olarak sınıfland1r1lır (Jurjević ve ark., 2020; Zeybek ve Vatandaşlar 2021). Halbuki, 3B nokta bulutundan gövde hacminin doğru ve hassas şekilde hesaplanabilmesi için gövdenin büyük kısmının gözle görülebilmesi gerekmektedir. Bunun mümkün olmadığı ağaçlarda, gövdeye yeterli nokta düşmemekte, dolayısıyla veride gövde formu iyi temsil edilememektedir. $\mathrm{Bu}$ durumda, özellikle çap ve hacim gibi meşcere parametrelerindeki hata oranları artmaktadır. Bununla birlikte, söz konusu hataların LiDAR verisinden kaynaklanabileceği gibi arazideki yersel ölçümlerden de kaynaklanabileceği unutulmamalıdır. Örneğin; 50, 90 ve 91 numaralı alanlarda LiDAR ile tespit edilen ve arazide ölçülen ağaç sayıları arasındaki uyumsuzluklar, örnek alanların ort. çap değerlerinde farklılıklara neden olmuştur. Ancak, $\% 95$ güven düzeyinde yapılan istatistik testler bu farklılıkların önemli olmadığını ortaya koymuştur.

LiDAR yönteminin bir diğer dezavantaj1; büyük verilerin işlenmesi ve depolanması için güçlü donanıma ihtiyaç duyulmasıdır. Bu araştırma çalışmasında ort. bir dizüstü bilgisayar (i5 işlemci, 8 GB RAM, 4GB ekran kartı) kullanılmasına rağmen verinin ön işlenmesi ve analiz edilmesinde ciddi zaman harcanmıştır. Örneğin, 142 numaralı örnek alan verisinin GeoSLAM Hub programiyla ön işlenerek ".las" uzantılı hale getirilmesi $14 \mathrm{dk}$. sürmüştür. Aynı örnek alana ait nokta bulutunun analiz edilmesi de $10 \mathrm{dk}$. almıştır. Bu süreler, daha zor örnek alanlarda katlanarak artmaktadır. Orman amenajman planı yenileme çalışmaları kapsamında tek bir OİŞ’ne yüzlerce örnek alan düştüğü düşünülürse (OGM, 2017), büyük verinin bu şekilde işlenmesi, analiz edilmesi ve yorumlanması oldukça zaman alacaktır (Vatandaşlar ve Zeybek 2021). Bu nedenle, LiDAR yönteminin büro çalışmalarına harcanan süre daha yüksek donanımlı bilgisayarlar ya da iş istasyonları ile kısaltılabilir.
Diğer yandan, büyük verinin kişisel bilgisayarlarda (PC) depolanması da ayrı bir problemdir. $400 \mathrm{~m}^{2}$, $600 \mathrm{~m}^{2}$ veya $800 \mathrm{~m}^{2}$ 'lik daireler şeklinde kesilen nokta bulutlarının her birinde yaklaşık 50 milyon nokta bulunmaktadır. Böyle bir nokta bulutu verisi yaklaşık $600 \mathrm{MB}$ alan kaplamaktadır. Meşcerenin boyu, sıklığı, dallar ve diri örtü yoğunluğu arttıkça örnek alan boyutları da artmaktadır. Nokta bulutu verisine yardımcı veri kaynakları da (ham veri, yörünge dosyaları, video kaydı, rapor vb.) eklendiğinde tek bir örnek alana ait veri tabanı GB'lar ile ifade edilir hale gelmektedir. Türkiye'deki Oİş'lerinin oldukça geniş alanlara sahip oldukları düşünülürse, buralardan toplanan LiDAR verisinin depolanması ve dijital ortamda arşivlenmesi için özel sunuculara (server) ihtiyaç duyulacaktır.

LiDAR yöntemi, çapı 8 cm'e yakın olan ağaçların bol sayıda bulunduğu ab, b ve bc gelişme çağlarındaki yapraklı karışık meşcerelerin bakımsız sahalarında verimli çalışmamaktadır. Benzer şekilde, gövdenin alt kesimleri sık dallanmış sırıklık ve direklik çağındaki sıkışık ladin meşcerelerinde de çap çıkarımında problemler yaşanmıştır (Şekil 11). Bu tip meşcerelerde geleneksel envanter yöntemlerine (yersel ölçüm) devam edilmelidir. Çünkü bu durum, kullanılan LiDAR cihazından (ZEB-HORIZON) ya da Şavşat'taki çalışma alanından kaynaklanmamaktadır. Nitekim, bir başka cihaz (ZEB-REVO) ile Trabzon ve Artvin-Merkez ormanlarında yapılan çalışmalarda da benzer problemlerle karşılaşılmıştır (Vatandaşlar ve Zeybek, 2020, 2021; Zeybek ve Vatandaşlar, 2021). Dolayısıyla, LiDAR yöntemiyle orman envanterinden azami (maks.) fayda sağlanmak isteniyorsa; kaliteli (silindirik) gövdelere sahip saf ve tek katlı meşcereler, endüstriyel ve diğer ağaçlandırma sahaları, dikili ağaç satışı uygulamasının yapıldığı gençleştirme bölmeleri, çalı ve diri örtü bulunmayan düşük eğimli (maks. \%30-40) orman arazilerinde öncelikli olarak çalışılmalıdır.

Özellikle yapraklı meşcerelerde LiDAR ile taramalar vejetasyon dönemi dışında yapılabilir. Yapraklı ağaç türleri bu dönemde yapraklarını dökeceğinden gövdenin üst kısmı LiDAR verisinde daha net olarak modellenecektir. Bunların haricinde, LiDAR ile envanter yöntemine özel yeni örnekleme tasarımları geliştirilmelidir.

299 Sayılı Tebliğ'de (OGM, 2017) geleneksel yersel ölçümler düşünülerek geliştirilmiş örnek alan büyüklükleri, şekli ve alana dağılım desenleri uyarınca gerçekleştirilen veri alımları, LiDAR yönteminin verimliliğini kısıtlamaktadır. İleride bölmecik bazında tam alan ölçümü ya da şeritler halinde tarama gibi farklı örnekleme desenlerinin iş verimliliği ve tahmin doğruluğu araştırılmalı- 
dır. Örneğin Del Perugia ve ark. (2019), İtalya'da farklı örnekleme desenleri ve tarama güzergahlarının veri kalitesi ve iş verimliliği üzerine etkilerini araştırmışlar ve kestane meşcereleri için ideal tarama güzergahının birbirine $10 \mathrm{~m}$ mesafeli paralel şeritler olduğu sonucuna ulaşmışlardır. Ülkemizde de bu tip araştırmalar yapılarak hangi örnekleme deseninin hangi meșcere tipleri için daha uygun olacağ $\breve{1}$ belirlenmelidir. Diğer taraftan, orman amenajmanında güncel uzaktan algılama teknolojilerine uyumlu şekilde geliştirilecek inovatif örnekleme tasarımları ile el tipi LiDAR nokta bulutları havasal LiDAR nokta bulutuyla bütünleştirilebilir. Bu sayede, el tipi LiDAR ile yerden toplanan veriler, insanstz hava araciyla (IHA) havadan toplanan verilerle kaynaştırılarak (füzyon) çok daha geniş sahaların hızlı envanterini gerçekleştirmek mümkündür.

Sensör ve robotik alanındaki gelişmelere paralel olarak LiDAR sistemlerinin maliyetleri giderek düşse de, el tipi mobil LiDAR cihazının Türkiye'deki fiyatı kişisel kullanım için hala yüksektir. Günümüzdeki modellerin tümü ithal ürün olduğu için yüksek döviz kurlarından olumsuz etkilenmektedir. İleride yerli LiDAR sensörlerinin geliştirilmesi ya da mevcut teknolojideki gelişmeler sonucunda satın alma maliyetlerinin de düşeceği tahmin edilmektedir.

Teknolojideki baș döndürücü ilerlemeler birçok ormancılık uygulamasının yapılış şeklini değiştirmiştir. Geçmişte baskı harita, açı̈llçer, pusula ve ip kullanılarak gidilen örnek alanlara, günümüzde el GPS'i ile rahatlıkla ulaşılabilmektedir. İleride LiDAR yönteminden yararlanılarak yapılacak orman envanterleri ve buradan sağlanan bilgilere dayalı olarak hazırlanacak orman amenajman planları da, tıpkı bugün herkes tarafından aktif olarak kullanılan GPS teknolojisi gibi hızla yaygınlaşarak ormanc1lık uygulamalarında ana akım haline gelebilir.

$\mathrm{Bu}$ araştırma çalışmasında orman envanterlerinde ihtiyaç duyulan göğüs çapı, birim alandaki ağaç sayısı, hakim ağaç boyu, gövde hacmi, meşcere hacmi ve kapalılık parametrelerinin el tipi mobil LiDAR sistemi ile arazide daha az zaman harcanarak kabul edilebilir doğruluk düzeylerinde hesaplanabildiği Artvin-Şavşat’taki uygulama örnekleriyle somut olarak gösterilmiştir. El tipi mobil LiDAR teknolojisinin orman amenajmanı yanı sıra dikili ağaç satışlarındaki verim yüzdesi hesabı, ulusal orman envanterleri, yanan alanlardan çıkarılacak enkaz odunların hacimlendirilmesi, meşcere profillerinin çıkarımı, çeşitli hasılat çalışmaları gibi birçok uygulamalı ormancılık alanında da ileride etkin bir şekilde kullanılabileceği düşünülmektedir.

\section{Teşekkür}

El tipi mobil LiDAR cihazını temin etmemizi sağlayan OGM OİPD'ne, arazi çalışmalarımıza destek veren Artvin OBM'ne, makale metnini gözden geçirerek önerilerde bulunan OİPD Orman Modelleme ve Hasılat Şube Müdürü Gediz Metin KOCAELİ, Amenajman Rehberlik ve Denetim Başmühendisi Armağan YALÇIN ve Dr. Öğr. Üyesi Mehmet SEKI'ye teşekkür ederiz. Ayrıca makalenin incelenmesi ve güçlendirilmesi için vakit ayırarak, önemli katkılarını bizlerden esirgemeyen hakemlere şükranlarımızı sunarız.

\section{Kaynaklar}

Akalp, T., 1978. Türkiye'deki Doğu Ladini (Picea orieantalis Lk. Carr) Ormanlarında Hasılat Araştırmaları. Doktora Tezi, İ.Ü. Orman Fakültesi, İstanbul.

Alemdağ, Ş., 1966. Türkiye'deki Sarıçam Ormanlarının Kuruluşu, Verim Gücü ve Bu Ormanların İşletilmesinde Takip Edilecek Esaslar. Doçentlik Tezi, İ.Ü. Orman Fakültesi, İstanbul.

Beucher, S., Lantuejoul, C., 1979. Use of Watersheds in Contour Detection. In: International Workshop on Image Processing: Real-Time Edge and Motion Detection/ Estimation, Rennes.

Cadge, S., 2016. Welcome to the ZEB REVOlution. GEOmedia, 20(3): 22-25.

de Conto, T., Olofsson, K., Gorgens, E. B., Rodriguez, L. C. E., Almeida, G., 2017. Performance of stem denoising and stem modelling algorithms on single tree point clouds from terrestrial laser scanning. Computers and Electronics in Agriculture, 143: 165-176. doi:10.1016/j. compag.2017.10.019

Del Perugia, B., Giannetti, F., Chirici, G., Travaglini, D., 2019. Influence of scan density on the estimation of single-tree attributes by hand-held mobile laser scanning. Forests, 10(3): 277-290.

Eraslan, İ., 1982. Orman Amenajmanı. İstanbul Üniversitesi Orman Fakültesi Yayınlar1, No: 3010/318, İstanbul.

Hijmans, R. J., 2021. raster: Geographic Data Analysis and Modeling. https://CRAN.R-project.org/ package $=$ raster Erişim tarihi: 4 Kasım 2021.

Hyyppä, E., Kukko, A., Kaijaluoto, R., White, J. C., Wulder, M. A., Pyörälä, J., Liang, X., Yu, X., Wang, Y., Kaartinen, H., Virtanen, J.-P., Hyyppä, J., 2020. Accurate derivation of stem curve and volume using backpack mobile laser scanning. ISPRS Journal of Photogrammetry and Remote Sensing, 161: 246-262. doi:10.1016/j. isprsjprs.2020.01.018

Illingworth, J., Kittler, J., 1987. The adaptive hough transform. IEEE Transactions Pattern Analysis and Machine Intelligence, 9(5): 690-698. doi:10.1109/tpa- 


\section{mi.1987.4767964}

Jurjević, L., Liang, X., Gašparović, M., Balenović, I., 2020. Is field-measured tree height as reliable as believed - Part II, A comparison study of tree height estimates from conventional field measurement and low-cost close-range remote sensing in a deciduous forest. ISPRS Journal of Photogrammetry and Remote Sensing, 169: 227-241. doi:10.1016/j.isprsjprs.2020.09.014

Kalıpsız, A., 1984. Dendrometri. İstanbul Üniversitesi Orman Fakültesi Yayınları, No: 3194/354, İstanbul

Kayacan, B, Zengin, H, Kadiogulları, A.I., 2016. Chapter 44: Turkey. In: Vidal C, Alberdi I, Hernandez L, Redmond J (editors). National Forest Inventories: Assessment of Wood Availability and Use. Cham, Switzerland: Springer, pp. 807-827.

Liu, L., Zhang, A., Xiao, S., Hu, S., He, N., Pang, H., Zhang, X., Yang, S., 2021. Single tree segmentation and diameter at breast height estimation with mobile LiDAR. IEEE Access, 9: 24314-24325. doi:10.1109/access. 2021.3056877

Lukács, G., Marshall, A. D., Martin, R. R., 1997. Geometric least-squares fitting of spheres, cylinders, cones and tori. RECCAD, 2: 671-675.

MGM, 2012. Meteoroloji Genel Müdürlüğü Artvin ili Şavşat ilçesi İklim İstasyonuna ait rasat verileri. http:// www.mgm.gov.tr/veridegerlendirme/il-ve-ilceler-istatistik.aspx\#sfU (Ziyaret tarihi: 13.10.2021).

Miraboğlu, M., 1955. Göknarlarda Şekil ve Hacim Araştırmaları. OGM Yayınları, Seri No: 5, Ankara.

OGM, 2013. Orman Genel Müdürlüğü, Veliköy Orman İșletme Şefliği Ekosistem Tabanlı Fonksiyonel Amenajman Planı (2013-2032), Ankara.

OGM, 2017. OGM Orman İdaresi ve Planlama Dairesi Başkanlığ 1 , Ekosistem Tabanlı Fonksiyonel Orman Amenajman Planlarının Düzenlenmesine Ait Usul ve Esaslar (299 sayılı tebliğ-düzeltmeli son baskı), Ankara.

Orhan, F., 2015. Şavşat'ın beșerî ve ekonomik coğrafyası (1. baskı). Şavşat Belediyesi Kültür Yayınları, Artvin.

Qiu, Z., Feng, Z., Jiang, J., Lin, Y., Xue, S., 2018. Application of a continuous terrestrial photogrammetric measurement system for plot monitoring in the Beijing Songshan National Nature Reserve. Remote Sensing, 10(7). doi:10.3390/rs10071080
Rousseeuw, P.J., Leroy, A.M., 1987. Robust Regression and Outlier Detection: John Wiley \& Sons, ABD, New York.

Schnabel, R., Wahl, R., Klein, R., 2007. Efficient RANSAC for point-cloud shape detection. Computer Graphics Forum, 26(2): 214-226. doi:10.1111/j.14678659.2007.01016.x

Trochta, J., Krucek, M., Vrska, T., Kral, K., 2017. 3D Forest: An application for descriptions of three-dimensional forest structures using terrestrial LiDAR. Plos One, 12(5): e0176871. doi:10.1371/journal.pone.0176871

URL-1. http://forsys.cfr.washington.edu/fusion/fusion overview.html, 11.02.2014. Erişim tarihi: 14 Ekim 2021.

URL-2. http://www.rslab.se/2017/10/17/terrestrial-laserscanner/ Erișim tarihi: 14 Ekim 2021.

URL-3. https://geoslam.com/ Erişim tarihi: 14 Ekim 2021.

Vatandaşlar, C., Zeybek, M., 2020. Application of handheld laser scanning technology for forest inventory purposes in the NE Turkey. Turkish Journal of Agriculture and Forestry, 44(3): 229-242. doi:10.3906/tar-1903-40

Vatandaşlar, C., Zeybek, M., 2021. Extraction of forest inventory parameters using handheld mobile laser scanning: A case study from Trabzon, Turkey. Measurement, 177. doi:10.1016/j.measurement.2021.109328

Venables, W.N., Ripley, B.D., 2002. Statistics and Computing ( $4^{\text {th }}$ ed.). Springer, New York

Wang, Y., Pyörälä, J., Liang, X., Lehtomäki, M., Kukko, A., Yu, X., Kaartinen, H., Hyyppä, J., 2019. In situ biomass estimation at tree and plot levels: What did data record and what did algorithms derive from terrestrial and aerial point clouds in boreal forest. Remote Sensing of Environment, 232. doi:10.1016/j.rse.2019.111309

Yurtseven, H., Coban, S., Akgul, M., Akay, A. O., 2019. Individual tree measurements in a planted woodland with terrestrial laser scanner. Turkish Journal of Agriculture and Forestry, 43(2): 192-208. doi:10.3906/tar$1805-5$

Zeybek, M., Vatandaşlar, C., 2021. An automated approach for extracting forest inventory data from individual trees using a handheld mobile laser scanner. Croatian Journal of Forest Engineering, 42(3): 515-528. doi:10.5552/crojfe.2021.1096 